\title{
THE CONSTITUTION AND THE SHARING OF WEALTH IN CANADA
}

\author{
Paul Davenport*
}

\section{INTRODUCTION}

The sharing of wealth among the provinces in Canada is one of the central parts of the country's federal system. Canada's provinces differ enormously in size, population, resource wealth, and income per capita, and some form of interprovincial redistribution of revenues or income is essential to national unity. Moreover, the sharing of wealth has always been in part a constitutional issue in Canada. Sections 118 and 119 of the British North America (BNA) Act of $1867^{1}$ included a specific statement of subsidies to be paid by the federal government to the provinces, with higher per capita subsidies to the Maritime provinces than to Central Canada. ${ }^{2}$ In the forty years that followed, the subsidies were continually changed until a 1907 amendment to the BNA Act set down a new scale. ${ }^{3}$ The BNA Act also gave the provinces jurisdiction over spending on health, education, and welfare. ${ }^{4}$ As the importance of these areas of government spending expanded in the twentieth century, so too did the importance of revenue sharing, since the poorer provinces could fairly claim that their own revenue bases were insufficient to permit them to fulfill their constitutional responsibilities in social programs. Thus it is largely for constitutional reasons that the current system of wealth sharing through equalization payments is often called "the glue that holds Confederation together." 5

There are two sections of the Constitution Act, 1982, which are of direct importance to the sharing of wealth: Part III, on equalization, and Part VI, on natural resources revenues. ${ }^{6}$ The entrenchment of a specific equalization formula was suggested in 1968 by the Government of Nova Scotia, ${ }^{7}$ which thought the move would reduce fiscal tensions in Canada. The 1982 Act stops short of specifying a

Copyright (C) 1983 by Law and Contemporary Problems.

* Department of Economics; Chairman of Canadian Studies, McGill University. The support of a research grant from the Social Sciences and Humanities Research Council of Canada is gratefully acknowledged. I would also like to thank John Graham, James Dean, Derek Hum, and Robert Armstrong for helpful comments on an earlier draft of this paper.

1. British North America Act, 1867,30 \& 31 Vict., ch. 3 [hereinafter cited as the BNA Act, 1867].

2. At Confederation, the Maritime provinces were Nova Scotia and New Brunswick; Central Canada included Ontario and Quebec.

3. British North America Act, 1907, 7 Edw. 7, ch. 11.

4. BNA Act, $1867, \S \S 92$ and 93 .

5. Task Force on Fiscal Arrangements, Fiscal Federalism in Canada 157 (1981),

6. Constitution Act, 1982, 1980-81-82 Can. Stat., [hereinafter cited as Constitution Act, 1982] Parts III \& VI.

7. Cf. D. Smiley, Canada in Question: Federalism in the Seventies 115 (2d ed. 1976). 
formula, for reasons which will become apparent below. Instead, the Act sets out the general principles which should guide equalization. Part III of the 1982 Act reads as follows:

Equalization and Regional Disparities

36.(1) Without altering the legislative authority of Parliament or of the provincial legislatures, or the rights of any of them with respect to the exercise of their legislative authority, Parliament and the legislatures, together with the government of Canada and the provincial governments, are committed to

(a) promoting equal opportunities for the well-being of Canadians;

(b) furthering economic development to reduce disparity in opportunities; and

(c) providing essential public services of reasonable quality to all Canadians.

(2) Parliament and the government of Canada are committed to the principle of making equalization payments to ensure that provincial governments have sufficient revenues to provide reasonably comparable levels of public services at reasonably comparable levels of taxation. ${ }^{8}$

Part VI of the 1982 Act $^{9}$ amends Section 92 of the BNA Act of $1867,{ }^{10}$ which sets out the exclusive powers of the provincial legislatures. The 1982 Amendment is concerned with the taxation and control of natural resources, a vital part of wealth sharing in Canada. This issue was of concern to the provinces because of two recent Supreme Court decisions ${ }^{11}$ overturning legislation by the Government of Saskatchewan, which had sought to fix prices and control production in two major resource industries: potash and oil and gas. Part VI authorizes the provinces to enact laws regulating the export of natural resources to another part of Canada and to enact laws imposing any mode of taxation on natural resources, as long as such laws do not discriminate between production which is exported and production which is consumed in the province. The role of natural resources, and of this Amendment, in wealth sharing in Canada will be considered below.

While Parts III and VI of the Constitution Act, 1982, are important, neither one will change fundamentally the way wealth is shared in Canada. The process of redistributing revenues among the provinces will continue to be determined by federal-provincial negotiations, whose form and content will be little changed by the recent constitutional reform. ${ }^{12}$ Yet the texts are significant, because they will be two elements in the complex combination of obvious self-interest and apparent feeling for national unity that underlies the unruly world of federal-provincial fiscal relations. The purpose of this paper is to explore the relationship between these texts and the current fiscal arrangements in Canada. For example, with

8. Constitution Act, 1982, Part III, $\S 36(1) \&(2)$.

9. Constitution Act, 1982, Part VI.

10. BNA Act, $1867, \S 92$.

11. Canadian Indus. Gas \& Oil Ltd. v. Government of Saskatchewan, 80 D.L.R.3d 449 (Can. 1977); Central Canada Potash Co. v. Government of Saskatchewan, 88 D.L.R.3d 604 (Can. 1978). For a discussion of the former case, see Paus-Jenssen, Resource Taxation and the Supreme Court of Canada: The Cigol Case, 5 Can. Pub. Pol'y 45 (1979). For a discussion of the Potash case, see Bushnell, The Control of Natural Resources through the Trade and Commerce Power and Aoprietary Rights, 6 CAN. PUB. POL'y 313 (1980).

12. Thus while Part III entrenches the principle of equalization, and Part VI authorizes the provinces to levy both direct and indirect taxes on natural resources, the actual equalization formula and payments, and the overall federal-provincial distribution of resource rents will continue to be determined by federalprovincial negotiation and compromise. The mixing of political and economic concerns in such negotiations during the period 1964 to 1968 is described by R. Simeon, Federal-Provincial Diplomacy: The Making of Recent Policy in Canada, ch. 4. (1972). 
regard to Part III, what is the relationship between "services of reasonable quality" and "reasonably comparable levels of taxation," 13 and are both goals achievable with our current equalization formula? If not, what amendments to the current formula seem desirable?

The sections cited in the Constitution Act, 1982, will serve as a basis for reexamining our system of wealth sharing in Canada. While I have tried to keep the paper technically simple, it is still necessary to deal with many economic concepts not found in everyday language, and to examine the quantitative importance of variations in our equalization rules. The use of economic jargon and statistics in this area is the subject of the following scathing passage by Donald Smiley:

\begin{abstract}
Like prostitutes and golfers, those concerned with fiscal relations have developed their own argot, their own specialized vocabulary for communicating among themselves and mystifying outsiders. Thus we have "contracting out" and "tax room" and "fiscal equivalents" and "revenue equalization" and so on. In very recent years two new terms, "indexation" and "deconditionalization", have been added to this ghastly lexicon-certainly travesties of at least one of Canada's official languages if not of sound public policy. Nowhere more than in federal-provincial economic relationships is the threefold classification of falsehoods as "lies, damned lies and statistics" so applicable, and nowhere do Canadian politicians so embellish their pursuit of the crassest of purposes with appeals to the elegancies of economic analysis or what purport to be immutable principles. It is unlikely that in these matters the limits of chicanery have yet been reached. ${ }^{14}$
\end{abstract}

Whether the present paper reaches new levels of chicanery is for the reader to judge. This paper's purpose is to cut through the confusions and cross purposes which underlie our current equalization formula, and to show how it might be put on a more secure footing. A brief historical review of federal payments to the provinces designed to reduce disparities in provincial government per capita revenues is presented first. Two possible goals of equalization are then considered: tax equity and fiscal redistribution. The current representative tax system approach to equalization and a macroeconomic alternative are then reviewed. Two special problems with equalization are analyzed next: its impact on provincial incentives and its role in redistributing natural resource revenues. Finally, the importance of efficiency and national unity in the equalization program are considered.

\title{
II
}

\section{The Historical Roots of Equalization}

Today, as in 1867, federal-provincial fiscal relations involve two sorts of "balances." The concept of "federal-provincial fiscal balance" implies an appropriate distribution of revenues between the two levels of government, so that each level is able to finance its expenditure responsibilities; this notion of balance groups the provinces together as a whole. "Interprovincial fiscal balance," on the other hand, involves the reduction of disparities in revenue capacity and expenditure responsibilities among the provinces.

Concern with the federal-provincial balance could cause transfers of taxing powers or cash payments from one level of government to the other, while concern

13. Constitution Act, 1982, Part III, §§ 36(1)(c) \& (2).

14. D. SMILEY, supra note 7 , at 114 . 
with interprovincial balance is the basis of Canada's equalization program. Thus, in his presentation to the recent Task Force on Fiscal Arrangements, Minister of Finance Allan MacEachen called for a restraint in the growth of federal transfers to the provinces to correct a federal-provincial fiscal imbalance, evident in the growing federal budget deficit in the face of an overall provincial government surplus. ${ }^{15}$ The overall provincial surplus, however, masked an increasing interprovincial imbalance, with surpluses in the three westernmost provinces and deficits elsewhere. ${ }^{16}$

The drafters of the BNA Act faced these same problems of federal-provincial balance and interprovincial balance; ${ }^{17}$ they dealt more directly and successfully with the first than with the second. ${ }^{18}$ The BNA Act effected a massive transfer of expenditure responsibilities from the provinces to the new federal government; to maintain the federal-provincial balance, an equally important transfer of revenues was enacted. ${ }^{19}$ On the expenditure side, the parliament of Canada assumed responsibility for some $\$ 89$ million in net debt which the provinces of Canada, Nova Scotia, and New Brunswick had accumulated, ${ }^{20}$ largely in the construction of railroads and canals. ${ }^{21}$ The corresponding physical assets were also transferred to the federal government, which henceforth would be responsible for large-scale investments in transportation facilities. ${ }^{22}$

On the revenue side, section 92 of the BNA Act of $1867^{23}$ limited the provinces to direct taxation, reserving to the federal government customs and excise duties, which together accounted for nearly $60 \%$ of total revenue of $\$ 19.5$ million in the three provinces in $1866 .{ }^{24}$ Section $118^{25}$ dealt directly with the issue of federalprovincial balance, establishing an annual transfer from the federal government to the provinces of about $\$ 2.7$ million, presumably because the reduction in provin-

15. A. Maceachen, Federal-Provincial. Fiscal Arrangements in the Eighties 8, i2 (1981).

16. Id. at 8, and Table II-6, at 39 .

17. Report of the Royal Commission on Dominion-Provincial Relations, Book 1, at 36-46 (1940) [hereinafter cited as Report]. See also D. Creighton, British North America at ConfederaTION, at $79-91$ (1940).

18. My account of the fiscal aspects of Confederation to 1940 is taken mainly from the REPORT, supra note 17, especially Book 1, chapters 1 and 2; the classic study for the Commission, D. CREIGHTON, BRITISH North America at Confederation (1940); the standard text, A. MoOre, J. Perry \& D. Beach, The Financing of Canadian Federation: THE First Hundred Years (1966); two scholarly works by Maxwell, A Flexible Portion of the British North America Act, CAN. BAR REv. 11 (1933) [hereinafter cited as Maxwell (1933)], and Federal Subsidies to the Provinclal Governments in Canada (1937) [hereinafter cited as J. MAXWELL (1937)]; and a careful chronology of federal-provincial financial agreements from 1864 to 1927 in A. Boos, The Financial Arrangements Between the Provinces and The DOMINION (1930).

19. BNA Act, 1867, §§ 91, 102-126; J. MAXWell (1937), supra note 18, at ch. 1; A. Boos, supra note 18 , ch. 1 .

20. REPORT, supra note 17 , Book 1, Table 5A, at 42 .

21. Id., Book 1, at 37-39; D. CREIGHTON, supra note 17, at 75-79.

22. REPORT, supra note 17 , Book 1 , at 41.

23. BNA Act, $1867, \S 92$.

24. REPORT, supra note 17 , Book 1 , Table 4 , at 40 .

25. BNA Act, 1867, $§ 118$. 
cial revenues otherwise enacted was felt to be greater than the reduction in provincial expenditure responsibilities. ${ }^{26}$

Behind the issue of federal-provincial balance, however, lurked some serious problems of interprovincial disparities. In a speech at Sherbrooke in late 1864, A.T. Galt, Finance Minister for the Province of Canada, presented estimates of provincial deficits after Confederation based on the planned transfers of revenues and expenditures to the federal government. As indicated in lines 1 to 3 of Table 1 , he projected a deficit of 38 cents per capita in the Province of Canada, $\$ 1.70$ in Nova Scotia, and \$1.33 in New Brunswick. ${ }^{27}$ The delegates to the Quebec Conference of 1864 were thus faced with the following problem: given that a federal subsidy to the provinces was required for federal-provincial fiscal balance, should the per capita subsidy vary among the provinces according to the projected deficits or some other measure of fiscal need? After a vigorous debate on the issue, Resolution 64 of the Conference proclaimed the principle of an equal per capita subsidy for each province, implying that a correction for interprovincial balance was unnecessary or undesirable. ${ }^{28}$ But Resolution $65^{29}$ allowed an exception to this principle: New Brunswick, because of its particular fiscal problems, might be allowed a special grant for a limited period.

These two Resolutions were embodied in Sections 118 and 119 of the BNA Act, ${ }^{30}$ with the results indicated in lines 4 to 7 of Table 1 . The principle of equal per capita grants resulted in a payment of $80 \leftarrow$ per person based on the 1861 population. This was well below Galt's estimate of the Maritime deficits, but well above the projected deficit for the provinces of Ontario and Quebec. Three concessions were made to interprovincial balance, however: a lump sum payment to each province (line 4 in Table 1), which amounted to about $6 \mathbb{}$ per capita for Ontario and Quebec, but $18 \$$ to $20 ₫$ per capita in the Maritimes; a ten-year special payment to New Brunswick of $\$ 63,000$, or $25 \llbracket$ per capita (line 6 in Table 1 ); and a difference of $\$ 2.85$ in allowable debt per capita between New Brunswick and Ontario and Quebec (line 9 of Table 1). Since the federal government was to collect (or pay) interest at $5 \%$ on the difference between actual and allowable debt, ${ }^{31}$ the $\$ 2.85$ difference in allowable debt was worth $14 \uparrow$ per capita to New Brunswick.

26. D. CREIGhTON, supta note 17, at 85, 86; J. MAXWELL (1937), supra note 18, at 6-14; REPORT, supra note 17 , Book 1 , at $44-46$.

27. REPORT, supra note 17 , Book 1, at 30-45. Galt's speech was printed in the Toronto Globe (November 28, 1864) and also published by Galt himself: SPEeCH ON THE PROPOSED UNION OF THE British American Provinces (Montreal, 1864).

28. Cf. A. BOOS, supra note 18, at 8 , and the REPORT, supra note 17, Book 1, at 45, which states, "The prevailing individualism. which enforced representation by population in the political sphere assumed without question that the first principle of equity in the financial settlement was per capita equity."

29. The Resolutions of the Quebec Conference are listed in Parllamentary Debates on The Subject of the Confederation of The British North American Provinces 1-6 (1951); the debates were originally published by the Provincial Parliament of Canada (Quebec, 1865).

30. BNA Act, 1867, §§ 118, 119.

31. Id., $\$$ 112-116. 
Table 1

Provincial Finances at Confederation

(dollars per capita)

$\begin{array}{cccc}\begin{array}{c}\text { Province of } \\ \text { Canada }\end{array} & \text { Nova } & \text { New } & \text { Total } \\ & \text { Scotia } & \text { Brunswick } & \end{array}$

Galt estimates, 1864

1. Expenditures

.90

.52

2. Revenues

3. Deficit

Federal Subsidies BNA Act

4. Lump sumb

5. Grant in aid

6. Ten year payment

7. Total

1859 Agreement

8. Ten year payment

Allowable Debt

9. BNA Act

10. 1869 Agreement

11. Value of differential

12. Subsidies plus value of debt differential, $1869 \mathrm{c}$

13. Population, 1861 (thousands)

0

24.92

24.92

0

.86

2,508
2.02

.32

1.70

1.68

.35

1.33

1.08

.48

.60

$06-18$

.20

.80

.25

1.25

.08

.80

.02

.90

.25

0

.02

24.17

27.77

.14

1.37

27.77

27.77

25.07

331

252

3,091

aOntario and Quebec after 1867.

bPaid as $\$ 80,000$ to Ontario ( $\$ .057$ per capita), $\$ 70,000$ to Quebec ( $\$ .063$ per capita), $\$ 60,000$ to Nova Scotia, and $\$ 50,000$ to New Brunswick.

cLine 12 is the sum of lines 7, 8, and 11 .

Source: Report of the Royal Commission on Dominion-Provincial Relations, Book 1, at 45, 60; BNA Act, 1867, sections 118, 119; A. BoOs, The Financlal ARrangements Between the Provinces and the Dominion 19 (1930); 1861 population is from Historicial STatistics OF CANADA series A5-A8, at 14 (1965).

Section 118 says of the lump sum and per capita payments that "Such Grants shall be in full Settlement of all future Demands on Canada,"32 a bold statement which held up for just two years. In 1868 Nova Scotia appealed to the Imperial government to repeal the Union, and then submitted a list of fiscal grievances to the new Dominion government. ${ }^{33}$ In 1869, despite vigorous protests from Ontario, Nova Scotia was granted the same benefits as New Brunswick: a $25 \$$ per capita payment for ten years, and an allowable debt of $\$ 27.77$ per capita. ${ }^{34}$ Thus, as line 12 of Table 1 indicates, by 1869 the equal per capita subsidy principle had been

32. Id., § 118.

33. A. Boos, supra note 18 , at 16 .

34. Dominion Statutes, 1869-70, ch. 2; $c$. J. MAXwell (1937), supra note 18, at 28; A. Boos, supra note 18 , at 19 . 
bent to the point that the subsidy in the Maritimes was some $60 \%$ above that in Central Canada.

Interprovincial balance was thus an essential part of the political economy of Confederation right from the start, and has been so ever since. Indeed one could argue that the ad hoc arrangements with New Brunswick and Nova Scotia in the 1860's set the pattern for wealth and revenue sharing in Canada for the next ninety years, until the tax sharing arrangements of 1957 formally introduced the principle of revenue equalization based on tax yields. Canada's first-century grants to provinces in financial difficulty were made on an ad hoc basis in response to provincial political pressure. Just as Nova Scotia had threatened to leave the Union in 1868, so New Brunswick had threatened not to join in $1864 .{ }^{35}$ In the words of George Brown, who believed in local taxation and was a critic of large federal subsidies: "New Brunswick imperatively demanded $\$ 63,000$ per annum beyond her share, and we had either to find that sum for her or give up the hope of Union." "36

In a similar manner, special arrangements were made to attract and then retain in the Confederation the provinces of Manitoba, Prince Edward Island, and British Columbia, all of which joined the Dominion between 1870 and 1873. ${ }^{37}$ In 1907 an amendment to the BNA Act raised the grants to all nine provinces (including Alberta and Saskatchewan, which joined in 1905) according to a rather complicated schedule based on population, but there was also a special ten-year grant to British Columbia. ${ }^{38}$ While the schedule is described as "a final and unalterable settlement,"39 haggling over federal subsidies continued unabated in the twentieth century. The three Maritime provinces presented a continual problem because of their below average personal incomes and government revenues. The 1926 Duncan Commission recommended that the statutory payments to the three provinces be nearly doubled, with an increase of $\$ 875,000$ to Nova Scotia, $\$ 600,000$ to New Brunswick, and $\$ 125,000$ to Prince Edward Island. ${ }^{40}$ The federal government accepted this proposal, and then raised the Duncan grants by a total of $\$ 875,000$ in 1934 , on the recommendation of the White Commission. ${ }^{41}$

The depression of the thirties led to severe financial difficulties in all provinces, as revenues collapsed and expenditures soared for welfare and unemployment relief. The federal government responded with grants-in-aid and loans totalling about $\$ 500$ million to provincial and municipal governments in all provinces.

35. J. MaXwell (1937), supra note 18, at 23-26.

36. A. Boos, supra note 18 , at 10 (quoting G. Brown, Province of Canada, Confederation DEBATES 93 (1865)).

37. Id., at chapter 3.

38. BNA Act, 1907, 7 Edward 7, ch. 11.

39. Maxwell (1933), supra note 18, at 155. Maxwell reviews the efforts to arrive at a "final" system of federal subsidies, beginning with the statement of section 118 of the BNA Act, 1867: "Such grants shall be in full settlement of all future demands on Canada . . . ." He shows that such declarations have in no way impeded an almost continuous tampering with the levels of the subsidies.

40. J. Maxwell (1937), supra note 18, at 144.

41. Id. at 184 . 
Special grants were also made to the four western provinces. ${ }^{42}$ The uneven regional incidence of the depression, which was particularly severe on the prairies, brought to the fore the lack of a coherent framework for maintaining interprovincial fiscal balance in Canada. In 1937 the Royal Commission on DominionProvincial Relations was appointed to study the issue of fiscal balance and recommended changes in Canada's fiscal arrangements.

In its report the Commission dealt directly with the problem of interprovincial balance, proposing a system of "National Adjustment Grants" rather similar to our current system of equalization payments. The Commission described the grant as follows: "[T] he adjustment grant proposed is designed to enable a province to provide adequate services (at the average Canadian standard) without excessive taxation (on the average Canadian basis) ..." 43 We will see below that the phrase "without excessive taxation" can be interpreted in two ways; one is compatible with the existing equalization formula based on government revenue, and another would imply a macroeconomic approach to equalization, based primarily on personal income.

An equalization scheme similar to the National Adjustment Grants approach was adopted by Canada in 1956 in the Federal-Provincial Tax-Sharing Arrangements Act. ${ }^{44}$ Under this Act $10 \%$ of federal personal income tax, $9 \%$ of corporation profits, and $50 \%$ of federal succession duties were to be equalized among the provinces, using as a standard the average per capita yield for the two provinces with the highest yield. Provinces below the standard would receive an equalization payment to bring them up to the standard. ${ }^{45}$ This formula, which is based on govemment revenue, was first proposed by Prime Minister St. Laurent at a federalprovincial conference in Ottawa in October 1955.46 At the same conference the Province of New Brunswick tabled an equalization formula based on personal income, which would pay equalization to those provinces with per capita personal income less than $85 \%$ of the national average. The per capita payment would be a fraction of the difference between $85 \%$ of average personal income and personal income in the recipient province; the fraction would be equal to the ratio of total provincial and municipal government revenue in Canada to total personal

42. REPORT, supra note 17, Book 1, at 160-77, has an excellent account of provincial fiscal problems and federal responses during the thirties.

43. REPORT, supra note 17 , Book 2, at 84 .

44. Federal-Provincial Tax-Sharing Arrangements Act, 1956, 4 \& 5 Eliz. 2, ch. 29, §§ 3, 4 [hereinafter cited as Tax-Sharing Act, 1956]. The description of equalization arrangements since 1957 is derived from A. MacEachen, supta note 15; J. Lynn, Federal-Provincial Fiscal Relations (1964); R. Simeon, Federal-Provincial Diplomacy: The Making of Recent Policy in Canada (1972); D. Smiley, supra note 7; P. Lewis, The Tangled Tale of Taxes and Transfers, in Canadian ConfEDERATION AT THE Crossroads (M. Walker ed. 1978); and various issues of Canadian Tax J. (published by the Canadian Tax Foundation), including an excellent article by Perry, The Federal-Provincial Fiscal Anangements Introduced in 1977, 25 CAN. TAX J. 429-40 (1977).

45. In fiscal 1957-58, Ontario and British Columbia had the highest per capita yields under the formuta. In 1958, the federal government raised the equalized share of personal income tax from $10 \%$ to 13\%; see A. MOORE, J. Perry, \& D. BEACH, supra note 18, at 58, 60. J. LYNN, supre note 44, at 74-76, discusses both the tax-sharing and equalization provisions of the 1956 Act.

46. A. MoOre, J. Perry, \& D. Beach, supra note 18, at 49. 
income. ${ }^{47}$ New Brunswick's was a macroeconomic approach to equalization; a similar formula has recently been suggested by Milton Moore, ${ }^{48}$ while the macroeconomic approach of the New Brunswick proposal has been supported by Paul Davenport. ${ }^{49}$

The equalization formula adopted in the 1956 Tax-Sharing Arrangements Act ignored natural resource revenue ${ }^{50}$ in the calculation of equalization. This led to the bizarre result that the per capita payment in $1957-58$ to Alberta (\$10.32) was higher than the payment to Quebec (\$9.74), even though per capita personal income and resource revenue were higher in Alberta than in Quebec by $\$ 169$ and $\$ 106$, respectively. ${ }^{51}$ Pressure thus mounted to include natural resource revenue in the equalization formula. However, a problem arises here: if resource revenues were simply added to the 1956 formula, then Ontario would have become eligible for a payment, despite the fact that per capita personal income in Ontario was about $19 \%$ above the national average. This anomalous result occurs because the yields of the standard taxes (individual and corporate income taxes and succession duties) which were equalized amounted to only about $2.3 \%$ of personal income in 1962-63. Thus while the formula might count a dollar of resource revenue as a dollar, it counted a dollar of personal income as less than $3 \mathbb{4}$, precisely because the formula focused on govermment revenue alone. This problem of the uneven treatment of resource revenues and personal income became acute after 1972 with the sharp increase in energy prices, and still plagues the equalization program today.

To avoid a payment to Ontario, the federal government adopted an expedient which it has employed many times over the past two decades. To overcome the problems of an equalization formula based solely on government revenue, it simply changed the parameters of the formula in an ad hoc manner, while continuing to calculate the payments on the basis of government revenue alone. Thus in a statement to a federal-provincial conference in Ottawa in February 1961, Prime Minister Diefenbaker proposed two changes to the existing equalization formula: natural resource revenues would enter the formula, but only one-half of these revenues would be included, and the equalization standard would become average revenue in all provinces, rather than the average in the two provinces with highest revenue. ${ }^{52}$ The Prime Minister said of this adjustment: "The reason only half of these revenues is provided is to make allowance for the variation in the rates of tax or charge imposed by various provinces, and to avoid discouraging the develop-

47. New Brunswick's proposal is reproduced in A. MOORE, J. PERRY, \& D. BEACH, supra note 18, at 126.

48. M. Moore, The 1982 Renewal of the Tax Collection and Related Agreements: One Western View (paper presented to the Canadian Economics Ass'n Annual Meeting, Halifax, May 27, 1981 ).

49. P. Davenport, Equalization Payments and Regional Disparities (paper presented to the Canadian Economics Ass'n Annual Meeting, Saskatchewan, May 30, 1979).

50. Natural resource revenues are the royalties, rental payments, and lease payments collected by provincial governments from forestry operations, oil and gas production, other mineral production, and the use of water power; see Perry, supra note 44, at 430-32.

51. Data in this paragraph on tax yields and equalization payments for 1957-58 and 1962-63 are from A. MoOre, J. Perry, \& D. BeACh, supra note 18, at Tables 13, 16, and 18. Data on personal income and personal income per capita are from MINISTER OF FINANCE, ECONOMIC REVIEW 1982 (1982), Reference Tables 16 and 17.

52. Reprinted in A. MOORE, J. Perry, \& D. BEACH, supra note 18, at 130. 
ment of these sources of revenue." 53 Neither of these reasons is convincing: the one-half ratio in no way corrects for provincial tax differences, and since equalization payments for resource revenues are not financed by taxes on resource revenues the payments can hardly discourage resource development. In my view, both the one-half ratio for resource revenues and the change in standard to the national average were designed to prevent a payment to Ontario. The one-half weight for resource revenue is in fact an implicit recognition of the uneven treatment of western resources and Ontario personal income in the standard equalization formula. ${ }^{54}$

Prime Minister Diefenbaker's proposal was put into effect for the 1962-63 fiscal year ${ }^{55}$ but in 1964-65 the formula was changed again, ${ }^{56}$ to fulfill a campaign promise of Prime Minister Lester Pearson that the equalization standard would be returned to average revenue in the two provinces with the highest revenue. To avoid making a large payment to Ontario, resource revenues were removed from the standard revenue yield, but then to avoid payments to Alberta and British Columbia, resource revenues in excess of the national average per capita were deducted from the grant otherwise payable. These ad hoc adjustments, like those of the Diefenbaker government, are additional evidence of the problems induced by a formula which focuses only on government revenue.

One of the losers from the inclusion of natural resource revenues in the 1962 formula, and their use as a deduction in 1964, was Saskatchewan, which had (and still has) below average personal income per capita but above average resource revenues. ${ }^{57}$ Prime Minister Pearson announced the new fiscal arrangements for 1964-65 at a federal-provincial conference in Ottawa in November 1963.58 Premier Lloyd of Saskatchewan promptly attacked the federal proposal as unfair to his province, particularly with regard to the treatment of resource revenues.59 This paper will show that from a macroeconomic perspective the current equalization formula is indeed unfair to provinces with high resource revenues and low personal incomes.

In 1967-68, the current system of equalization was established.60 The three standard taxes were replaced by a formula which included all provincial taxes, and has thus become known as the "Representative Tax System."61 Although the

53. Id.

54. Cf. A. Moore, J. Perry, \& D. Beach, supra note 18 , at 85.

55. The Federal-Provincial Fiscal Arrangements Act, 1962-63 Can. Stat., ch. 14.

56. The Federal-Provincial Fiscal Revision Act, 1964 Can. Stat., ch. 26; A. MOORE, J. PERRY \& D. BEACH, supra note 18 , at $74,82-85$.

57. See Tables 3 and 4 below.

58. A. MOORE, J. PerRy \& D. BeACh, supra note 18, at 81-85.

59. Id. at 85. Ross Thatcher, who succeeded Lloyd as Premier in 1964, threatened to pull the Provincial Liberal Party out of the National Liberal Party if Prime Minister Pearson implemented the tax-indicator approach in 1966. The final settlement included a special transition payment to Saskatchewan-in 1965-66-67 Can. Stat., ch. 89, $\$ 9(2)$ - but it is unclear whether the payment was directly related to Thatcher's protest; see R. SimEON, supra note 44, at 75-76.

60. Federal-Provincial Fiscal Relations Act, 1967, 1965-66-67 Can. Stat., ch. 89.

61. The Representative Tax System was explained in masterful essays by James Lynn in CoMPARING Provincial Revenue Yields: The Tax Indicator APProach (1968) and by Douglas Clark in Fiscal NeEds and ReVenue Equalization Grants (1969). Both Lynn and Clark became distinguished mem- 
equalization standard reverted to the national average, total payinents rose by $55 \%$ in the year the new system was introduced because of the inclusion of so many additional provincial revenue sources. ${ }^{62}$ Provincial non-resource revenues were now great enough that all resource revenues could be included in the formula without a payment to Ontario. Provincial revenues were divided into 16 sources in 1967-68; the number rose to 19 in 1972-73, 20 in 1973-74, and 29 in 1977-78.63

The new equalization system remained unchanged during its first five years, but then ran into trouble when the rapid increase in the prices of oil and gas after 1973 led to a corresponding increase in resource revenues in the three westernmost provinces. These new revenues would have required large increases in equalization payments, and eventually a payment to Ontario; the Ontario payment would have been $\$ 660$ million in $1977-78$, and $\$ 1.7$ billion in 1980-81.64 The federal government adopted the same expedient as in 1962-63 when resource revenues were introduced into the formula system: it changed the parameters of the formula. In 1974-75 two-thirds of all new oil and gas revenues due to price increases after 1973 were removed from the formula; 65 this provision was replaced in 1977-78 by two new changes designed to limit payments on account of natural resources. ${ }^{66}$ In 1982-83, the federal government simply removed Alberta from the calculation of the equalization standard, 67 thereby removing about $85 \%$ of

bers of the Federal-Provincial Relations Branch of the Department of Finance. Even those who, like the present author, believe that the Representative Tax System has serious flaws, must admire the skill with which this relatively complex fiscal formula was introduced and administered at the Department of Finance.

62. Total payments rose from $\$ 355$ million in $1966-67$ to $\$ 552$ million in $1967-68$; see A. MacEACHen, supra note 15, Table V-1, at 63. The Representative Tax System was chosen in preference to an approach based on personal income, which had been suggested by New Brunswick in 1955 (see supra note 47). The two approaches were compared in papers presented by federal officials to a federal-provincial meeting on fiscal arrangements in February 1966. At subsequent meetings in July and September 1966, Nova Scotia strongly supported a macroeconomic approach based on total income, but the federal government's preference was for the Representative Tax System, which was ultimately adopted. See R. SIMEON, supra note 44 , at $66-85$, for an excellent account of federal-provincial fiscal negotiations during 1965 and 1966.

63. The original 16 revenue sources in 1967-68 are listed in D. ClaRk, Fiscal NeEds AND REvenUE Equalization Grants (1969), Table VI, at 39-40 [hereinafter cited as D. Clark (1969)]. The growth in the number of revenue sources from 1967-68 to 1977-78 is described by A. MACEACHEN, supra note 15, at 68. The 29 sources in 1977-78, which are listed in Perry, supra note 44, at 431, include: personal and corporate income taxes; general sales taxes; taxes on tobacco and gasoline; alcohol revenues; natural resource revenues; and various other taxes and provincial government revenues.

64. Per capita figures are from Davenport, supra note 49, at Table 1 and from Table 3 below; these must be multiplied by the Ontario population to get the numbers in the text.

65. Federal-Provincial Fiscal Arrangements Act, 1972, 1972 Can. Stat., ch. 8, as amended by 1974-75 Can. Stat., ch. 65; section 1 of the latter statute describes the new treatment of resource revenues.

66. The Federal-Provincial Fiscal Arrangements and Established Programs Financing Act, 1977, 1976-77 Can. Stat., ch. 10. Sections 4(2) and 4(7) of the 1977 Act included only one-half of non-renewable resource revenues in the equalization formula, and put a limit of one-third on the share of total equalization payments which could be paid on account of natural resource revenues; $\S 4(2)$ lists the 29 revenue sources included in the formula. In 1981, equalization payments on account of natural resources were further reduced by the ad hoc removal of the revenues from the sale of leases on Crown oil and gas lands. 1980-81-82 Can. Stat., ch. $46, \S 1(1)$; in 1980-81 the revenues involved were $\$ 952$ million. As compared to including one-half of these revenues in the formula, removing them entirely reduced equalization payments by $\$ 172$ million in 1980-81. See DeP'T of Finance, Provinclal Fiscal Equalization Tables: Fourth Estimate, 1980-81, Summary Table 13 and Computation Table 20 (1981).

67. The 1982 amendments to The Federal-Provincial Fiscal Arrangements and Established Programs Financing Act, 1977, changed the standard of equalization payments from average provincial government 
Canada's oil and gas revenues from the formula. ${ }^{68}$

This constant ad hoc reformulation of the program renders the incorporation of equalization in the Constitution of dubious significance: does it make sense to entrench a federal program whose payments are frequently changed and redistributed at the will of the federal government, on the pretense that the program is one of the fundamental principles on which the country is based? It is high time to rethink the equalization program, in order to put it in a more permanent framework.

Rethinking equalization requires a careful re-examination of the Representative Tax System. One of the recent changes to the equalization program denied a payment to any province with personal income per capita above the national average. ${ }^{69}$ This personal income override was directed at Ontario, which otherwise would have been eligible for a payment in the late 1970 's. ${ }^{70}$ After objecting to this provision, the Task Force on Fiscal Arrangements notes that "This issue raises difficult problems of perception and may cast some doubts on the continued validity of the measures of fiscal capacity currently employed."71 One of the themes of this paper is that the frequent ad hoc adjustments to the current program should cast doubts on the validity of the Representative Tax System as a framework for equalization. Indeed, the frequent changes remind one of the situation with regard to tax rentals in $1955,{ }^{72}$ before the 1956 equalization formula was introduced, as described by Moore, Perry, and Beach: "the formulae used for calculating payments under the rental agreements had become a disarray of improvisations and were badly in need of overhauling. The three bases had neither uniformity nor principle but had been designed to yield the amount of money each province would accept to enter an agreement."73

One source of the difficulties of the current equalization system is its concentration on government revenue and neglect of personal income. The recent Task Force on Fiscal Arrangements compares the current Representative Tax System approach to equalization, based on government revenue, with an alternative

revenue in all provinces (including Alberta), to the average revenue in five provinces-British Columbia, Manitoba, Ontario, Quebec, and Saskatchewan-thereby excluding Alberta's wealth from the equalization formula. 1980-81-82 Can. Stat., ch. $94, \S 2$.

68. The $85 \%$ figure is from Economic Council of Canada, Financing Confederation, Table B1 , at 147 (1982).

69. Federal-Provincial Fiscal Arrangements and Established Programs Financing Act, 1977, 1976-77 Can. Stat., ch. 10, as amended by 1980-81-82 Can. Stat., ch. 46, $\$ 1(2)$.

70. On the relation between the override and Ontario's eligibility, see Courchene \& Copplestone, Aliemative Equalization Programs: Two Tier Systems, Fiscal Dimensions OF CaNadian FederalisM, at 1516 (R. M. Bird ed. 1980), and TASk Force ON Fiscal ARRAngements, supra note 5, at 166-69. The override was passed by parliament in 1981, but was retroactive to 1977-78, when Ontario first became eligible for a payment.

71. TASK Force on Fiscal ARRangements, supra note 5, at 168.

72. The tax rental arrangements were begun in 1941 to aid the federal government in financing the war effort. Provincial and municipal income taxes were terminated, allowing the federal government to levy uniform income taxes throughout the country. In return, the federal government transferred part of the collected taxes to the provinces. These transfers were called "tax rental payments," to indicate that the federal government was "renting" the provincial income tax base. The rental agreements are analyzed in A. MoOre, J. Perry \& D. BeAch, supra note 18, at ch. 2.

73. A. MOORE, J. PerRY \& D. BEACH, supra note 18 , at 46. 
macroeconomic approach based on an aggregate measure of income, including personal income. ${ }^{74}$ While both the federal government ${ }^{75}$ and the Task Force ${ }^{76}$ prefer the Representative Tax System, the macroeconomic approach is not without supporters. ${ }^{77}$ The theme of the present paper is that the choice between these two approaches should depend upon the goals of equalization, and in particular whether equalization is designed primarily to equalize tax rates among provinces or to redistribute income from high-income provinces to low-income provinces. In effect, we must determine the most sensible interpretation of the clause "reasonably comparable levels of public services at reasonably comparable levels of taxation" in Section 36(2) of the Constitution Act, 1982.

III

\section{TAX EQUiTy AND Fiscal Redistribution}

Fiscal equalization in Canada is a federal government program designed to promote equity among the residents of the various provinces. As applied to fiscal matters, however, "equity" is a slippery concept with at least two dimensions, horizontal and vertical. Horizontal equity consists of the equal treatment of equalsfor example, insuring that people with a given income face similar tax rates across the country. Vertical equity involves the proper treatment of unequals, such as the issues of whether or not those with higher incomes should face higher tax rates, as they do with a progressive income tax. The interpretation of equity is particularly difficult in a federal country like Canada, where overall equity depends crucially upon the independent taxing and spending policies of the various levels of government.

The current equalization formula in Canada is based on the following approach to tax equity: each province in Canada should be able to achieve the average level of government spending while levying average tax rates. ${ }^{78}$ In a truly federal country, however, it is both impossible and undesirable to impose identical systems of taxation and public services in all the provinces. Thus Canadian equalization grants are designed to give each province the possibility of achieving the average level of government spending while levying average tax rates; each province is then free to adjust its own levels of taxation and spending according to the desires of its citizens.

An alternative goal to tax equity is the redistribution of revenues from highincome provinces to low-income provinces, which we may call fiscal redistribution, with high and low income defined in terms not of government revenue, but of the total income available to provincial residents. The purpose of fiscal redistribution would be to reduce the sacrifice of private consumption necessary to achieve a

74. Task Force on Fiscal Arrangements, supto note 5, at 161-63.

75. A. Maceachen, Fiscal Arrangements in the Eighties: Proposals of the Government of Canada 12-16 (1981).

76. TASK Force on Fiscal ARrangements, supto note 5.

77. P. Davenport, supra note 49; M. Moore, supra note 48; Moore, Some Proposals for Adapting FederalProvincial Financial Agreements to Current Conditions, 24 CAN. PUB. AD. 232 (1981).

78. Courchene \& Beavis, Federal-Provincial Tax Equalization: An Evaluation, 6 CAN. J. EcoN. 483 (1973). 
given level of public services in poor provinces. Thus while tax equity is based on horizontal equity, fiscal redistribution is concerned with vertical equity. Equalization grants based on either tax equity or fiscal redistribution would allow recipient provinces to devote the grants either to increasing services or reducing taxes, so that the ultimate beneficiaries are the individuals in the recipient provinces. But equalization based on fiscal redistribution would be designed to increase the economic well-being of individuals in low-income provinces, rather than to equalize tax rates. Milton Moore argues strongly for a macroeconomic approach, with the objective of redistributing income "to reduce the inequality of welfare of persons." 79

The problems evident in our current tax equity approach to equalization seem to arise from the fact that when resource revenues are large and unequally distributed, tax equity may be inconsistent with fiscal redistribution. In other words, tax equity could demand that we transfer revenue from a province with low total income to one with high total income. In such a case we would require a clear consensus as to whether the purpose of equalization is tax equity or fiscal redistribution. Our problem in Canada over the last decade has been that there is no such consensus. The federal government continues to use a formula largely based on tax equity, but then overrides it in an ad hoc manner when the results appear inconsistent with fiscal redistribution, as when Ontario became eligible for equalization payments. ${ }^{80}$

In a 1980 budget paper the Government of Ontario stated that "a thorough reform of the equalization program is required as part of the solution to Canada's problems of regional imbalance."81 In my view the essential first step in such a reform is a consensus on the relative importance of tax equity and fiscal redistribution as goals of equalization. As will be shown below, giving priority to fiscal redistribution implies a preference for the macroeconomic approach to equalization, while the goal of tax equity would lead one to adopt a variant of the Representative Tax System (although perhaps not the one currently in use in Canada).

\section{A. The Representative Tax System}

Equalization payments are currently distributed according to a Representative Tax System (RTS), based on the revenue each province would collect if it taxed its various revenue sources at the average provincial rates. ${ }^{82}$ The current equalization formula is thus based solely on government revenue. In what follows we will consider an alternative macroeconomic formula based on total provincial incomes, including personal income and resource revenues.

Table 2 offers a hypothetical example to illustrate the operation of the current system and the macroeconomic alternative. Imagine a country with four provinces of equal population, so that country values of per capita variables are simple aver-

79. Moore, supra note 48 , at 246.

80. See supra notes $69,70$.

81. Government of Ontario, Equalization and Fiscal Disparities in Canada, in ONTAR 16 (1980).

82. J. LYNN, supra note 61, and D. CLARK (1969), supra note 63. 
ages of the four provinces. Per capita personal income $(Y)$ is 110 in region $A$, resource revenue $(R)$ is 2 , and their sum, total provincial income (TPI), is 112 . Personal income tax at the average provincial rate (assumed to be 0.2 ) is $T^{*}=22$. Revenue capacity (RC) in $A$ is thus $24 ; R C$ measures the revenues collected by the provincial government at average provincial tax rates. ${ }^{83}$ Regions $B$ and $C$ are poorer in personal income but rich in natural resources, and have higher government revenue than $A$. Region $D$ is poorer than $A$ by any standard. The RTS formula would rank the regions by $\mathrm{RC}$ as in line 5 and make payments to those with below average revenue to bring them up to the national average of 28 . Thus $A$ and $D$ both receive $\$ 4$ per capita in line 6 . Since all regions pay central government taxes to finance the program, $B$ and $C$ are made worse off by the existence of equalization.

\section{Table 2}

An Equalization Example

(dollars per capita)

\begin{tabular}{|c|c|c|c|c|c|c|}
\hline & & & & & & Average \\
\hline & & $\mathbf{A}$ & $\mathbf{B}$ & C & D & \\
\hline 1. $\mathrm{Y}$ & & 110.0 & 95.5 & 72.0 & 82.5 & 90.0 \\
\hline 2. $\mathbf{R}$ & & 2.0 & 12.5 & 18.0 & 7.5 & 10.0 \\
\hline 3. $\mathrm{T}$ & & 112.0 & 108.0 & 90.0 & 90.0 & 100.0 \\
\hline 4. $T$ & & 22.0 & 19.1 & 14.4 & 16.5 & 18.0 \\
\hline 5. $\mathrm{R}$ & & 24.0 & 31.6 & 32.4 & 24.0 & 28.0 \\
\hline 6. $\mathrm{E}$ & RC) & 4.0 & 0 & 0 & 4.0 & 2.0 \\
\hline 7. $\mathrm{E}_{2}$ & TPI) & 0 & 0 & 4.0 & 4.0 & 2.0 \\
\hline 8. $\mathrm{T}$ & & 33.0 & - & 0 & - & - \\
\hline 9. $\mathbf{T}$ & & 35.0 & - & 18.0 & - & - \\
\hline 10. $Y$ & & 77.0 & - & 72.0 & - & - \\
\hline Key & $\begin{array}{l}\mathrm{Y} \\
\mathrm{R} \\
\mathrm{TPI} \\
\mathrm{T}^{*} \\
\mathbf{R C} \\
\mathbf{E}_{1} \\
\mathbf{E}_{2} \\
\mathbf{T}\end{array}$ & $\begin{array}{l}\text { personal in } \\
\text { provincial } \\
Y+R \text {, tota } \\
0.2 Y \text {, prov } \\
T^{*}+R \text {, rev } \\
\text { equalizatio } \\
\text { provincial } \\
\text { equalizatio } \\
\text { TPI and } \mathrm{P} \\
\text { hypothetic }\end{array}$ & $\begin{array}{l}\text { iment } n \\
\text { ncial in } \\
\text { income } \\
\text { capacity } \\
\text { ulated } \\
\text { ulated } \\
\text { ial TPI } \\
\text { collecti }\end{array}$ & $\begin{array}{l}\text { resour } \\
\text { averag } \\
\text { differer } \\
\text {-tenths } \\
\text { A }(0.3\end{array}$ & $\begin{array}{l}\text { enue } \\
\text { rate of } \\
\text { ween } \\
\text { differ } \\
\text { C. }\end{array}$ & verage \\
\hline
\end{tabular}

RTS tax equity is here inconsistent with fiscal redistribution: tax equity requires that $A$, the region with the highest personal income before and after taxes,

83. We assume that resource revenue is collected by the same rules in all four provinces, so that no adjustment to actual revenue is required. 
be a recipient of equalization. The payment to $\mathrm{A}$ is designed to enable $\mathrm{A}$ to reach the average level of government revenue $(\$ 28)$ while levying the average personal income tax rate (0.2). Note that without equalization, if the citizens of $A$ wanted more government spending, they could raise provincial taxes above the average rate, as in lines 8 to 10 , in which a tax rate of 0.3 gives the residents of $A$ above average government revenue while retaining for $A$ the highest after tax personal income $(Y-T)$ in the country. Conversely, lines 8 to 10 show that $C$ could eliminate income taxes altogether, suffer a lower level of government revenue than $A$, and still not achieve the level of $Y-T$ in $A$. Nonetheless, the RTS goal of equal standardized tax rates demands that $A$ receive a payment at the expense of $C$.

The macroeconomic alternative to government revenue as the basis for equalization would be some measure of the total income available to provincial residents. In Table 2 we add personal income and resource revenues to get total provincial income (TPI). The equalization payments in line 7 are an arbitrary fraction-in this case four-tenths - of the difference between provincial TPI and the national average of 100 ; total payments are the same as in line 6 , but they are paid to the provinces poor in total income, $C$ and $D$.

The macroeconomic approach to equalization is thus based explicitly on fiscal redistribution: by transferring income from rich provinces to poor, it seeks to increase government services and/or lower taxes in the poor provinces, and thereby reduce the overall disparity of real incomes in the country. Note that the RTS equalization may actually increase the disparities in government services among provinces by transferring revenue from low-income provinces to highincome ones. This will be the case, for example, if government spending is a fixed fraction (say $30 \%$ in our example) of TPI plus equalization in each province. Then before equalization, government spending is 33.6 in $\mathrm{A}$ and 27 in $\mathrm{C}$, and this disparity will be increased by making an equalization payment to $A$ through the RTS formula. The TPI formula, on the other hand, will reduce disparities in both government spending and private consumption by paying equalization to provinces poor in TPI.

From the point of view of fiscal redistribution, the problem with the RTS is that it ignores personal income not paid out in provincial taxes, and thereby violates elementary principles of equity, including the Carter Commission principle that "a buck is a buck is a buck." 84 Thus in our example, in the computation of $\mathrm{RC}$ a dollar of provincial resource revenue counts as a dollar, while a dollar of personal income counts for only twenty cents. As long as resource revenues were relatively unimportant, government revenue was a good proxy for personal income, and the RTS seemed to work well. The rapid rise of energy prices and revenues after 1973, however, created a growing divergence between personal income and government revenue, and revealed the flaw in the RTS.

Rather than scrapping the RTS, however, the federal government has attempted a series of modifications designed to reduce the importance of resource revenues (which were the source of the breakdown in the RTS) and to prevent

84. Cf. E. Benson, Minister of Finance, Proposals for Tax Reform 36 (1969). 
Ontario from receiving payments (Ontario's eligibility was a graphic illustration of the dangers of ignoring personal income). In 1973-74 two-thirds of energy revenue increases due to price increases were removed from the formula; ${ }^{85}$ in $1977-78$ onehalf of all non-renewable resource revenues were removed from the formula and equalization payments from all resources were limited to one-half the payments from all other sources; ${ }^{86}$ and in 1981 revenues from the sale of Crown leases were removed from the formula. ${ }^{87}$ Despite all this ad hoc tinkering, Ontario was still eligible for payments; ${ }^{88}$ as a result, the 1981 amendments contained a provision removing Ontario's eligibility by declaring that provinces with above average per capita personal income were ineligible for payments. This personal income "override" was used to deny payments to Ontario in the five fiscal years from 1977-78 to $1981-82.89$

All of these modifications have not solved the basic problem of the RTS, which is its omission of personal income not paid out in provincial taxes. The personal income override would effectively rule out a payment to region $\mathrm{A}$ in Table 2, but it would do the same to a region $\mathrm{E}$ (say), with above average personal income, little resource revenue, and below average TPI. Moreover, the RTS will continue to deny payments to a region like $\mathrm{C}$, which is poor in personal income and TPI but rich in resource revenues. Nor are these idle examples. With oil and gas revenues, Newfoundland (or any other Atlantic Province) could soon look like region $\mathrm{C}$ and be denied equalization payments, while other provinces with higher TPI continue to receive them. Ontario, on the other hand, could one day approximate region $\mathrm{E}$. Ontario's personal income per capita relative to the national average fell from 1.18 in 1970 to 1.07 in 1980 ; $^{90}$ the province may fall below average in TPI within the next decade. ${ }^{91}$ The personal income override would have denied such a province an equalization payment.

In a document tabled with the budget on November 12, 1981, the federal government offered several proposals on equalization as part of the federal-provincial discussions on fiscal arrangements. ${ }^{92}$ The government proposed to maintain the current RTS formula, but beginning in 1982-83 per capita government revenue in Ontario, and not the national average, would be the standard to which low revenue provinces would be equalized. Moreover, all natural resource revenues would be included in the RTS formula, there would be no limit on the proportion of the payments due to natural resources, the personal income override would be removed, and total equalization payments would be constrained to grow no more rapidly than the gross national product. Such changes do not in fact resolve the basic problems of the RTS formula illustrated in Table 2; the problems will persist

85. 1974-75 Can. Stat., ch. $65, \S 1$.

86. 1976-77 Can. Stat., ch. $10, \S \S 4(2)$ and $4(7)$.

87. 1980-81-82 Can. Stat., ch. 46, § 1(1).

88. Dep't of Finance, Provincial Fiscal Equalization Tables: Fourth Estimate, 1980-81 (Oct. 9, 1981), Summary Table 1.

89. 1980-81-82 Can. Stat., ch. 46, § 1(2).

90. Minister of FinANCE, supra note 51 , Reference Table 17 , at 141 .

91. As indicated in Table 3 below, Ontario's natural resource revenue per capita is only about $10 \%$ of the national average, so Ontario would fall below average in TPI before it did so in personal income.

92. A. MacEAChen, supra note 15 , at 36 . 
as long as the equalization formula is based solely on government revenue with a dollar of resource revenue treated differently from a dollar of personal income. Moreover, as we shall see below, using $100 \%$ of resource revenues rather than $50 \%$ in the RTS formula reduces by one-half the amount of new resource revenues a poor province can acquire before losing all equalization payments.

On April 5, 1982, exactly one week after the Canada Act was given royal assent in Britain, Canada's House of Commons passed Bill C-97 which amends the Fiscal Arrangements Act of 1977, and describes the arrangements for the next five years. ${ }^{93}$ With regard to equalization, C-97 adopts the proposals of the November 1981 Budget Paper, mentioned above, with one exception: the new standard for equalization is not revenue in Ontario, but average revenue in five provinces: Quebec, Ontario, Manitoba, Saskatchewan, and British Columbia. Thus the government has found still another way to deal with the problems caused for the RTS formula by natural resources: in effect, Alberta has been removed from the equalization formula. Alberta's revenues will no longer have any bearing on the equalization program, as long as Alberta itself is not a recipient. For the purposes of equalization, Canada now consists of only nine provinces. ${ }^{94}$ Thus, just as the equalization program was being entrenched in the Constitution as a cornerstone of national unity, the program itself was changed so that its scope is no longer national. In my view, this unfortunate situation was entirely induced by the anomalies in the RTS formula.

Column 7 of Table 3 shows preliminary figures for equalization payments in 1980-81, calculated using the RTS formula. If all resource revenues were counted, total payments would be about $\$ 6.6$ billion including $\$ 1.7$ billion to Ontario. ${ }^{95}$ The modifications in place in 1980-81 remove over half of the resource revenue from the formula, ${ }^{96}$ and reduce total payments by almost one-half to $\$ 3.5$ billion. The actual per capita payment in column 7 is the difference in column 6 between average Canadian revenue of $\$ 1653$, and the provincial revenue, e.g., the payment for Newfoundland is $\$ 641=\$ 1653-\$ 1012$. Even with over half of resource revenue excluded, Ontario is below average in government revenue; it is denied a payment by the personal income override.

93. An Act to Amend the Federal-Provincial Fiscal Arrangements and Established Programs Financing Act, 1977, and to Provide for Payments to Certain Provinces, 1980-81-82 Can. Stat., ch. 94.

94. As indicated above, five provinces will enter into the calculation of the equalization standard, while four others (the Atlantic Provinces) will be involved in equalization as recipients. Alberta will not enter into either sort of calculation.

95. The $\$ 6.6$ billion figure is the sum of the various hypothetical payments in column 4 of Table 3 multiplied by the provincial populations.

96. See supra notes $91,92$. 
Table 3

Provincial Government Revenue from the Representative Tax System and RTS Equalization Payments, 1980-81

(dollars per capita)

\begin{tabular}{|c|c|c|c|c|c|c|c|}
\hline & $\begin{array}{l}\text { Natural } \\
\text { Resource } \\
\text { Revenue }\end{array}$ & $\begin{array}{l}\text { Other } \\
\text { Revenue }\end{array}$ & $\begin{array}{l}\text { Total } \\
\text { Revenue }\end{array}$ & $\begin{array}{l}\text { Hypothetical } \\
\text { Payment }\end{array}$ & $\begin{array}{l}\text { Excluded Natural } \\
\text { Resource Revenue }\end{array}$ & $\begin{array}{l}\text { Revenue } \\
\text { to be } \\
\text { Equalized }\end{array}$ & $\begin{array}{l}\text { Actual } \\
\text { RTS } \\
\text { Payment }\end{array}$ \\
\hline & (1) & (2) & (3) & (4) & (5) & (6) & (7) \\
\hline 1. Nfld. & 160 & 912 & 1072 & 738 & 60 & 1012 & 641 \\
\hline 2. PEI & 0 & 920 & 920 & 890 & 0 & 920 & 733 \\
\hline 3. N.S. & 19 & 1096 & 1115 & 695 & 8 & 1107 & 546 \\
\hline 4. N.B. & 61 & 1117 & 1178 & 632 & 18 & 1160 & 493 \\
\hline 5. Que. & 37 & 1333 & 1370 & 440 & 10 & 1361 & 292 \\
\hline 6. Ont. & 32 & 1578 & 1610 & 200 & 11 & 1599 & $(54)^{\mathrm{b}}$ \\
\hline 7. Man. & 44 & 1290 & 1334 & 476 & 17 & 1317 & 336 \\
\hline 8. Sask. & 490 & 1368 & 1858 & 0 & 281 & 1577 & 76 \\
\hline 9. Alta. & 2391 & 2141 & 4532 & 0 & 1372 & 3160 & 0 \\
\hline 10. B.C. & 364 & 1763 & 2127 & 0 & 143 & 1984 & 0 \\
\hline 1. Canada & 298 & 1512 & 1810 & 275 & 157 & 1653 & 148 \\
\hline 2. Totala & 7118 & 36094 & 43212 & 6560 & 3741 & 39467 & 3544 \\
\hline
\end{tabular}

aTotal value in millions of dollars; line 11 is line 12 divided by the population of the ten provinces in millions.

bOntario is denied a payment of $\$ 54$ per capita because of the personal income override; see text.

Source: Calculated from data in Department of Finance, Provincial Fiscal Equalization TABLES: Fourth Estimate, 1980-81 (1981).

B. The Macroeconomic Approach to Equalization

The suggested macroeconomic alternative to the Representative Tax System as a basis for equalization is Total Provincial Income (TPI), defined as the total income available to provincial residents before taxes. The Task Force on Fiscal Arrangements considers the use of a macroeconomic approach to equalization, but recommends that the RTS formula be maintained. ${ }^{97}$ The Task Force finds that among the disadvantages of the macroeconomic approach are that it requires a calculation of Gross Domestic Product (GDP) by province, which we may be unable to do with sufficient accuracy, and that total equalization would be reduced with a macroeconomic formula. ${ }^{98}$ Neither of these objections is correct; we will consider the second objection in the next section of the paper.

With regard to the calculation of provincial GDP, those familiar with the diffculty of estimating revenue from twenty-nine tax sources in the RTS ${ }^{99}$ would hesitate to claim that our current measures of GDP in the Provincial Economic Accounts ${ }^{100}$ are clearly inferior to the RTS numbers. Indeed the Task Force itself lists as one of the advantages of the macroeconomic approach its elimination of the

97. TASK Force On Fiscal ARRANGements, supra note 5, at 162.

98. Id.

99. The complexity of the calculations is apparent in Computation Tables 1 to 30 in DEP'T OF Finance, Provincial Fiscal Equalization Tables: Fourth Estimate, 1980-81 (Oct. 9, 1981).

100. Statistics Canada, Provincial Economic Accounts, Catalogue 13-213. 
need to make what are often "arbitrary judgments" in the calculation of revenue sources and tax bases for the RTS. ${ }^{101}$ Moreover, in my own view, provincial GDP is not the appropriate measure of income for the macroeconomic approach, because it includes incomes earned by non-residents. For the purposes of equalization we should measure TPI as the sum of three items: personal market income (personal income less transfers), federal transfers to individuals, and provincial government revenues at national tax rates from business incomes and natural resources. No new calculations are required: the first two items are standard parts of the national accounts, ${ }^{102}$ while the third is part of the existing RTS calculation.

TPI so calculated is shown in column 4 of Table 4 . While personal market income plus federal transfers alone give a fairly good indication of relative income levels among the provinces, they should be adjusted for certain kinds of government revenue from provincial sources. If two provinces were exactly the same, except that one had a great deal of natural resource royalty payments while the other had none, the first province would be better off, since it could offer its citizens more services and/or a lower level of taxation. The royalty payments may thus be seen as a net addition to personal income in the first province, precisely because they are not collected from personal income. This leads to a general rule: we adjust personal income by adding the revenue of those forms of government taxation whose incidence is not primarily upon personal income.

Thus, personal income in each province is not adjusted for tax receipts whose burden is primarily on provincial residents. For example, it would clearly be double counting to include provincial sales or personal income taxes in TPI, since their collection merely transfers income within the province from households to government. Natural resource revenues and taxes on corporations are included, however, on the grounds that they make a net contribution to provincial income. Taxes on corporations and royalties paid by resource corporations are reflected in either higher product price or lower corporate income. To the degree that the products are exported, or the corporations are owned outside the province, the incidence is on non-residents. Provinces with large accumulations of natural resources or corporate capital are thus seen as having higher provincial incomes, as reflected in the revenues collectable from these sources at average Canadian tax rates. This revenue can be used to increase government services or lower personal taxes for a given level of government services - in either case, provincial residents are better off. In a similar spirit, provincial transfer payments to individuals are not included in TPI, because for the most part they simply involve the redistribution of income within the province. If such transfers were included, a province could increase its equalization payment merely by cutting its own taxes and transfers. Federal transfers to individuals in each province are included in TPI, because they are financed by federal taxes in all provinces and they are not subject to provincial manipulation.

101. Task Force on Fiscal ARrangements, supra note 5, at 162.

102. Statistics Canada, National Income and Expendrrure Accounts, Catalogue 13-201. 
Table 4

Total Provincial Income and TPI Equalization Payments, 1980-81 (dollars per capita)

\begin{tabular}{|c|c|c|c|c|c|c|}
\hline nal & $\begin{array}{l}\text { Federal } \\
\text { Transfer } \\
\text { Payments }\end{array}$ & $\begin{array}{l}\text { Selected } \\
\text { Government } \\
\text { Revenue }\end{array}$ & $\begin{array}{l}\text { Total } \\
\text { Provincial } \\
\text { Income }\end{array}$ & $\begin{array}{l}\text { Income } \\
\text { Gap } \\
\text { Ratio }\end{array}$ & $\begin{array}{l}\text { TPI } \\
\text { Payment } \\
(\alpha=0.3)\end{array}$ & $\begin{array}{l}\text { Relative } \\
\text { Payment } \\
\text { TPI/RTS }\end{array}$ \\
\hline
\end{tabular}
Transfers to Persons

(1) (2)

1018

1. Nfid.

2. PEI

3. N.S.

4. N.B.

5. Que.

6. Ont.

7. Man.

8. Sask.

9. Alta.

10. B.C.

11. Canada

12. Totala
4589

5466

6495

5690

7882

9493

7743

7808

9972

9788

8638

206198
1182

1023

1040

818

756

874

799

574

847

800

19094
(3)
(4)

\section{5}

6704

7616

6909

8856

10431

8777

9218

13237

11176

9885

235972
(5)

.410

.322

.230

.301

.104

$-.055$

.112

.067

$-.339$

$-.131$

447

10680
(6)

717

647

524

624

277

0

295

187

0

152

3618
(7)

1.12

.88

.96

1.27

.95

.88

2.46

$-$

1.02

1.02

aTotal value in millions of dollars; line 11 is line 12 divided by the population of the ten provinces in millions.

Source by column:

1. Statistics Canada, Ministry of Supply and Services, National Income and Expenditure ACCOUNTS 1966-1980 Catalogue 13-201, Tables 35 and 42 (1982).

2. Statistics Canada, Ministry of Supply and Services, Provincial Economic Accounts, 1965. 1980 Catalogue 13-213, Table 8 , the sum of lines 12, 23, and 24 (1982).

3. Dep't of Finance, Provincial Fiscal Equalization Tables, Fourth Estimate 1980-81 summary Tables 15 (for population), 16, and 18 (1981).

4. The sum of columns 1 to 3 .

5. One minus column 4 divided by 9885 .

6. Column 4 times column 5 times 0.3

7. Column 6 of Table 4 divided by column 7 of Table 3 .

Column 5 of Table 4 shows the "income gap ratio," the difference between the average Canadian TPI of $\$ 9885$ and each province's TPI, expressed as a ratio to the Canadian TPI. Since we cannot wholly eliminate these gaps (as we do with the corresponding gaps in adjusted government revenue) because the resulting negative incentive effects would be too large, we require a rule which links equalization payments to the gaps. For purposes of illustration, we consider a rule which keeps the distribution of payments similar to what it is now: the per capita equalization payment is equal to a fraction $\alpha$ of provincial TPI multiplied by the income gap ratio. Writing $\mathrm{Y}$ for per capita TPI, e for the equalization payment, i for each province, and $\mathrm{c}$ for Canada, the rule is as follows:

$$
e_{i}=\alpha Y_{i}\left[\left(Y_{c}-Y_{i}\right) / Y_{c}\right]
$$

Thus in recipient provinces, the ratio of equalization to TPI $\left(e_{i} / Y_{i}\right)$ is a fraction $\alpha$ of the income gap ratio (shown in brackets in the equation). ${ }^{103}$ Total equalization

103. Note that $e_{i}$ falls (though $e_{i} / Y_{i}$ continues to rise) as $Y_{i} / Y_{c}$ declines below 0.5 . If this were thought undesirable, a flat payment could be established for very low-income provinces: when $\mathrm{Y}_{\mathrm{i}} / \mathrm{Y}_{\mathrm{c}}<$ 
payments are proportional to $\alpha$. Column 6 of Table 4 shows the TPI equalization payments when $\alpha=0.3$, which produces total payments of $\$ 3.6$ billion, slightly more than the RTS payments of $\$ 3.5$ billion.

The last column of Table 4 shows the ratio of TPI equalization payments to RTS payments. The importance of including personal income is apparent in the following three pairs of provinces: Prince Edward Island and Newfoundland, Nova Scotia and New Brunswick, and Manitoba and Saskatchewan. In each case the second province has more resource revenue per capita than the first, but personal income per capita is either greater in the first province or about equal in the two. Thus in all three cases the second province gains relative to the first when we switch from RTS to TPI payments, because the latter gives a heavy weight to personal income. Indeed, by neglecting personal income, the RTS system assigns a larger payment to Prince Edward Island than to Newfoundland, despite the fact that Newfoundland is a poorer province as measured by TPI or any other comprehensive measure of provincial income.

\section{Comparisons of the RTS and TPI Formulas}

Three of the most difficult problems which confront the equalization program in Canada are the instability of the size of the payments, the issue of resource revenues in poor provinces, and the treatment of Ontario. Comparing the RTS and TPI formulas, we may consider each of these in turn.

1. Size of the payments. As noted earlier, rising oil prices after 1972 led to large increases in equalization entitlements, inducing the federal government frequently to change the formula in order to keep the payments growing roughly in step with GNP. These changes would have been largely unnecessary with a TPI system in place, because resource revenues are only a small share of TPI (about $3.4 \%$ in 1980-81), and because TPI differences are only partly equalized. More generally, however, the issue of the size of equalization payments should be kept separate from the question of their distribution.

Having decided whether its primary goal is tax equity, fiscal redistribution, or something else, the federal government, in consultation with the provinces, should then choose a formula which distributes the payments in the desired manner. If the government has a constraint on the size of the payments-e.g., that they should grow at so many percent per year or at the same rate as the GNP104 - the payments as distributed by the chosen formula can be uniformly scaled up or down so as to reach the desired size. Thus $\alpha$ in equation (1) can be adjusted each

$0.5, \mathrm{e}_{\mathrm{i}}=0.5 \alpha \mathrm{Y}_{\mathrm{c}}$. This case does not currently arise in Canada: Newfoundland, the province with the lowest per capita $\mathrm{TPI}$, has $\mathrm{Y}_{\mathrm{i}} / \mathrm{Y}_{\mathrm{c}}=0.6$.

104. From 1972-73 to $1980-81$, actual equalization payments rose from $\$ 1,070$ million to $\$ 3,544 \mathrm{mil}$ lion, or from $1.02 \%$ of GNP to $1.22 \%$ of GNP. As line 12, column (4) of Table 3 indicates, however, without the modifications to the formula described in the text, payments in 1980-81 would have been $\$ 6,560$ million, or $2.26 \%$ of GNP. The federal government changed the formula to avoid such a rapid rise in equalization as a share of GNP; of. Courchene \& Copplestone, supra note 70, at 11-15. The 1982 amendments to the equalization formula explicitly declared that the growth of payments could not exceed the growth of the GNP; see 1980-81-82 Can. Stat., ch. 94, § 2(9). The GNP constraint was originally proposed by Finance Minister Allan MacEachen in A. MACEACHEN, supre note 15, at 36. 
year so that the payments grow at any desired rate, which could be decided at each five-year renegotiation. Such a procedure is surely preferable to the recent ad hoc efforts by the federal government to manipulate the formula which distributes the payments among the provinces so as to achieve a given total expenditure: e.g., reducing total payments after 1973 by progressively eliminating resource revenues, ${ }^{105}$ then proposing Ontario as the base, ${ }^{106}$ then seeking to increase the payments slightly by changing the proposed base from Ontario to the average of British Columbia, Saskatchewan, Manitoba, Ontario, and Quebec. ${ }^{107}$ This confusion of equitable distribution with the appropriate or desired size of the payments makes agreement on either goal highly unlikely.

It was noted above that the Task Force on Fiscal Arrangements objected to a macroeconomic approach to equalization in part because total equalization payable "would ... tend to be significantly less than that payable under the approach currently used." 108 This is only true if we constrain a parameter like $\alpha$ in (1) in some arbitrary manner, e.g., as equal to the share of provincial government spending in TPI. However, such a constraint is unwarranted; the macroeconomic approach is presumably based on the principle of fiscal redistribution, and there is no "right" amount of revenue to redistribute, any more than there is a "right" degree of progression to the tax system. Thus, if the federal government chooses the macroeconomic approach, by varying $\alpha$ it can adjust the payments to any desired total. ${ }^{109}$

2. Resource revenues in poor provinces. Under the RTS relatively small amounts of resource revenue can disqualify a low-income province from equalization, because the formula ignores its low level of personal income. Thus using the figures in column 7 of Table 3, with $50 \%$ of natural resource revenues included, an increase of just $\$ 762$ million in resource revenues in Newfoundland $(\$ 1314$ per capita) would eliminate equalization for that province, even though in terms of TPI it would remain poorer than Nova Scotia and Quebec. Using the new terms of the 1982 Fiscal Arrangements Act, ${ }^{110}$ with $100 \%$ of resource revenues and equalization to the average provincial revenue in five provinces (Quebec, Ontario, Manitoba, Saskatchewan, and British Columbia), only about $\$ 360$ million in new resource revenues ( $\$ 621$ per capita) is required in $1980-81$ to deprive Newfoundland of equalization. With the TPI system, any new resource revenue in Newfoundland would be properly weighted against the low level of personal income

105. See supra notes $65-66$ and accompanying text.

106. See supra note 92 and accompanying text.

107. The five-province proposal was made by Finance Minister MacEachen at the February 1982 Economic Summit in Ottawa, and was specifically designed to increase the total of equalization payments by $\$ 1$ billion as compared to an Ontario standard, according to Deborah Dowling, Fiscal Proposals Dismay Provinces, Financial Post, Feb. 13, 1982, at 6. She cites a Saskatchewan official who claims that "the federal proposal was ill-developed and it fell apart in five minutes." Ill-developed or not, the five-province standard was incorporated in the Fiscal Arrangements Act for 1982.

108. TASK Force ON Fiscal ARRANGements, supra note 5, at 162.

109. To protect poor provinces from federal budget cutting, equalization could be constrained by agreement (or constitutional amendment) to be no less than some fixed fraction of GNP.

110. D. Clark, Nole on Equalization and Resource Rents, in NATURAL Resource Revenues: A TEST OF FEderalism (A. Scott ed. 1976). 
there. Using column 4 of Table 4 , we can calculate that it would require $\$ 2295$ million in resource revenue ( $\$ 3954$ per capita) to bring Newfoundland to the new average TPI, and hence eliminate its equalization payment.

The Newfoundland example brings out clearly the difference between the macroeconomic approach and those equalization systems which would treat separately the revenue from natural resources. ${ }^{111}$ A separate equalization of natural resource revenue would mean that low-income provinces with natural resources would be expected to transfer funds to high-income provinces without resources, e.g., region $C$ in Table 2 would transfer some of its resource revenue to region $A$, which has a higher per capita income. This transfer from a low-income province to a high-income province would make no sense to those in the low-income province and might in any case be politically impossible. From the macroeconomic perspective, to insure equity where resource revenue is unevenly distributed, it is essential to integrate resource revenue into the total income available to the residents of the various provinces. This is precisely what the TPI system does. Thus we disagree with Doug Clark who argues that equalization should not be expected to accommodate the large increases in resource rents of the past decade, and that if one wishes to equalize these rents a separate government program should be created. ${ }^{112}$ In my view, resource rents can only be sensibly and equitably redistributed as part of a broader equalization scheme which includes personal income, precisely because low-income provinces should not be asked to transfer their rents to high-income provinces.

3. The treatment of Ontario. One element of the current RTS which met with disapproval by the Task Force on Fiscal Arrangements was the personal income override which prevented Ontario from receiving an equalization payment, although it has been eligible for one by the RTS formula since 1977-78. ${ }^{113}$ The Task Force recommended formally that "negotiations be directed toward an equalization formula that can apply uniformly to all provinces, without arbitrary or discriminatory special provisions."114 The Task Force failed to point out that the personal income override is clear evidence that the federal government itself recognizes that personal income has a role to play in equalization. In fact, discrimination among provinces is inherent in the RTS formula: one discriminates in order to correct the anomalies produced by ignoring personal incomes. Changing to the TPI system would remove the need for discrimination and allow the uniform treatment of provinces that the Task Force recommends, with a dollar of personal income in Ontario given the same weight as a dollar of resource revenue in Alberta. With reference to the anomalies produced by the RTS system, Milton Moore writes: "The best way to avoid such anomalous results is to drop the use of fiscal capacities altogether and not to treat government resource revenues as though they enriched the residents of a province, dollar for dollar, by more than any other form of

111. See Courchene \& Copplestone, supra note 70, and TASK Force on Canadian Unity 73 (1979).

112. See supra note 93 and accompanying text.

113. TASK Force on Fiscal ARrangements, supta note 5, at 166, 168, 169.

114. TASK ForCe ON Fiscal ARRANGements, supra note 5, at 169. 
income."115

IV

\section{Federal Transfers and Provincial Government Incentives}

In 1980 the federal government transferred $\$ 12.8$ billion to provincial governments and $\$ 16.6$ billion to individuals: total federal transfers were thus $\$ 29.4$ billion, or $10 \%$ of gross national product. ${ }^{116}$ Since many of these transfers are designed to help individuals or provincial governments in economic difficulty, they can create the classic insurance problem of moral hazard: if those experiencing economic difficulties are compensated, the compensation may induce behavior which increases the difficulties. Thomas Courchene argues that just such a problem currently exists with regard to the impact on provincial government employment policies of three federal transfer problems: equalization, cost-sharing in welfare expenditures, and unemployment insurance benefits to individuals. ${ }^{117}$

Following Courchene, we may assume that a provincial government pursues a policy which increases unemployment, such as raising the minimum wage or subsidizing business to create short-term jobs, in the expectation that when the jobs terminate those unemployed will be eligible for unemployment insurance benefits (UIB). The moral hazard problem exists because the federal government assumes many of the costs of the provincial policies, including all of the UIB and one-half of any welfare expenditures associated with long-term unemployment. In addition, since higher unemployment will generally lower revenue capacity, the federal government sweetens the pot for recipients of equalization by increasing the equalization payment when unemployment increases. Thus federal transfers may create an incentive for provinces to embark on policies which reduce employment.

A document of the Government of Quebec has recently deplored this same incentive system from a rather different point of view, by analyzing the very small return to the province from job creation programs. ${ }^{118}$ The document offers the following example. ${ }^{119}$ Suppose that in 1984 a Quebec government program succeeds in creating jobs at the average industrial wage of $\$ 16,500$ for 6,060 workers, all of whom were on UIB before becoming employed. The resulting $\$ 100$ million in wages is shared as follows: the workers have a net gain of $\$ 27$ million after all taxes and after losing the $\$ 54.8$ million in UIB which they received when they were unemployed; the Quebec government gets $\$ 10.2$ million in new revenues but loses $\$ 5.5$ million in federal transfers for a net gain of only $\$ 4.7$ million; other provinces receive an increase in equalization of $\$ 1.2$ million; the remaining $\$ 67.1$ million is a net gain to the federal government, including tax revenues from the wage income of $\$ 8.0$ million, a reduction in federal transfers to the provinces of

115. Moore, supre note 77 , at 248.

116. Minister OF FinANCE, supra note 51, Reference Tables 3 and 52.

117. Courchene, Avenues of Adjustment: The Transfer System and Regional Disparities, in CANADIAN CONFEDERATION AT THE CROSSROADS 155, 161, 168 (M. Walker ed. 1978).

118. Government of Québec, Ministère des Finances, Direction Générale de la Politique Fiscale, The Dynamics of Finances in Quebec (1981).

119. Id. at 13-15; Table 2 , at 14 . 
$\$ 4.3$ million, and a reduction of unemployment insurance benefits of $\$ 54.8$ million. ${ }^{120}$

After presenting this example, the Quebec document concludes that "most of the financial benefits of economic development in Quebec go to the federal government;" further, that the lack of a financial incentive for provincial governments to undertake development programs "is in itself a formidable, if not insurmountable, obstacle to reducing regional inequalities;" and finally, that these disincentives "have a greater impact on the provinces that receive equalization payments and on the provinces with a higher unemployment rate than the national average." 121 The reference to federal transfers as an "obstacle to reducing regional inequalities" is particularly significant in light of Part III of the Constitution Act, 1982, which commits the government of Canada to both equalization and the reduction of regional disparities in opportunities. ${ }^{122}$ The Quebec government implies that equalization and other federal transfers may in fact retard the development of Canada's poorer regions, because of the tendency of the payments to contract as the economy of a region expands. ${ }^{123}$

One solution to the problem posed by Courchene and the Government of Quebec would be to have the provincial governments which receive equalization also share in the funding of unemployment insurance, so that total federal transfers to them would increase when their economies expand. This would give the provincial governments themselves an incentive both to avoid policies which increase unemployment (the Courchene problem), and to pursue policies which increase employment (the Quebec government problem). Table 5 illustrates one way of integrating UIB and equalization, using the TPI system. Column 1 of the table shows the initial TPI equalization payment calculated from equation (1) using $\alpha=0.33$, chosen so that the total payment in column 4 is roughly the same as that in column 6 of Table 4 . Column 2 of Table 5 shows UIB per capita in each of the provinces. The UIB adjustment in column 3 is one-half the difference between the national average UIB ( $\$ 185$ per capita) and UIB in each province. The total payment is then the initial payment plus the UIB adjustment, which is positive for Saskatchewan and Manitoba and negative for Quebec and the Atlantic provinces.

120. These figures do not include an additional $\$ 4.2$ million which is collected from employers, of which $\$ 2.4$ million goes to the federal government, the remainder to the provincial government.

121. GOVERNMENT OF QUEBEC, supra note 118, at 14, 16.

122. See text accompanying notes 8-9.

123. The idea that federal transfers may in fact increase regional disparities is also a major conclusion of the paper by Courchene, supra note 117 . 
Table 5

TPI Equalization Payments Adjusted for Unemployment Insurance Benefits, 1980-81 (dollars per capita)

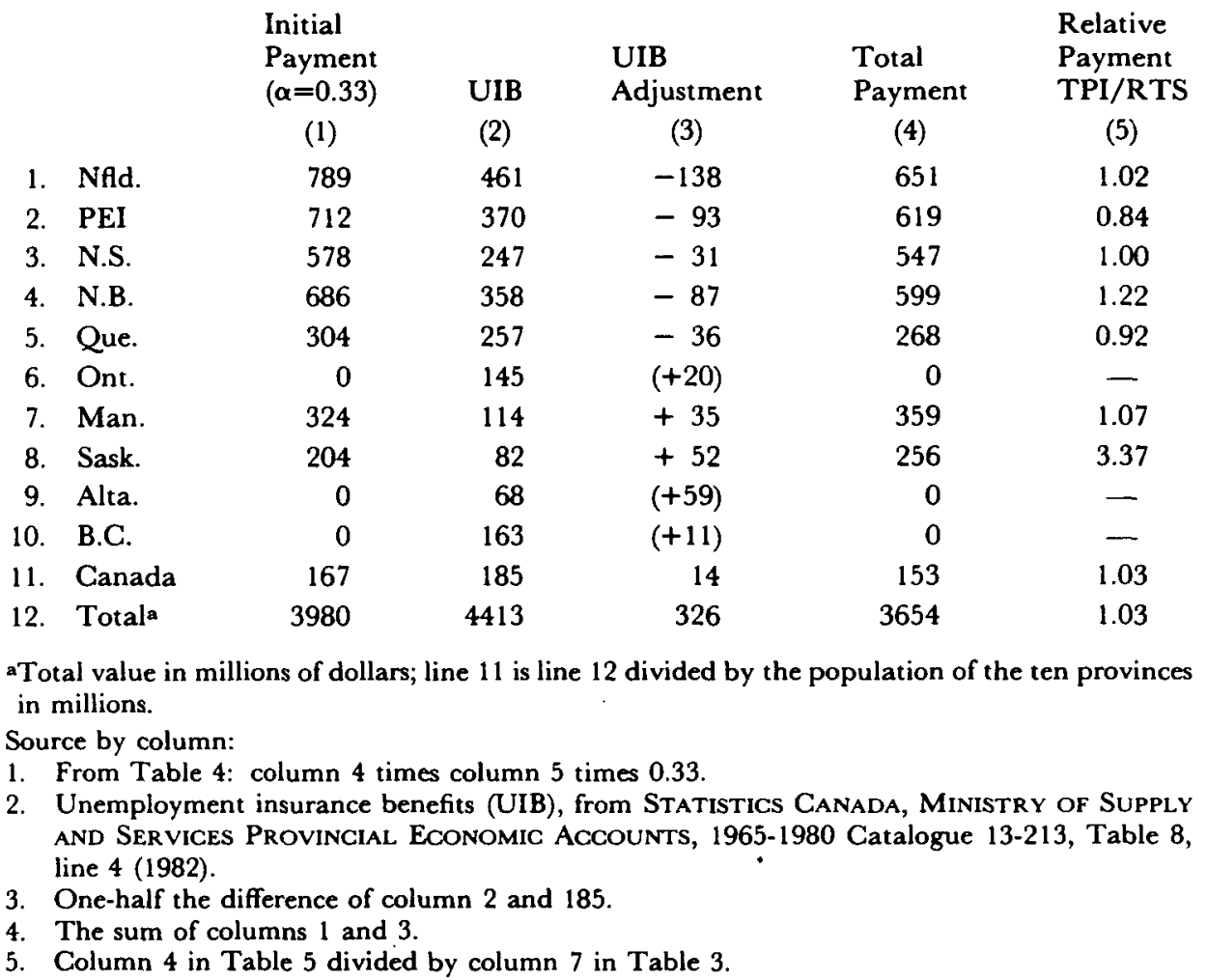

The UIB adjustment is thus a modified form of cost-sharing: the adjustment is based on the difference between provincial UIB and the national average in order to reduce the cyclical variation in the adjustment. Thus if the economy goes into a recession and the UIB increases by $\$ 50$ per capita in every province, there is no change in either the adjustment or the total equalization payment; if the UIB adjustment were simply one-half of UIB in each province, then equalization would fall by $\$ 25$ per capita in each recipient province. Thus the adjustment is designed. to reward those provinces which lower their demands on UIB relative to the national average, not to penalize all provinces simply because the national unemployment rate goes up.

Comparing column 4 of Table 5 with column 6 of Table 4 shows the effect of the UIB adjustment: while total payments are about the same, those provinces with relatively small UIB - Nova Scotia, Manitoba, and Saskatchewan-experience an increase in the total equalization payment, while the other four recipients experience a reduction. The purpose of the adjustment, however, is not this redistribution of equalization, but rather the change in provincial incentives. Consider the example given above from the government of Quebec, in which job creation reduces UIB in Quebec by $\$ 54.8$ million. With the UIB adjustment of Table 5, 
Quebec will now receive $36.8 \%^{124}$ of the reduction in UIB payments as an increase in equalization; this amounts to $\$ 20.2$ million which is added to Quebec's net gain and subtracted from the net gain of the federal government. Quebec now has a strong incentive to create jobs (or not to create unemployment) because both personal disposable income and federal transfers to the provincial government will rise (or will fall). Thus the provincial government will become more responsible for the result of its economic policies, as desired by Thomas Courchene ${ }^{125}$ and the government of Quebec. If the principle behind the UIB adjustment is accepted, one may be tempted to extend it to the provinces which do not receive equalization. I propose a method of doing so in the next section.

\section{V \\ Natural Resource Revenues and Equalization}

Natural resource revenues represent the Achilles heel of the current equalization system, with regard to both payments and financing. On the payments side, the concentration of natural resource revenues in the three westernmost provinces demands large equalization payments to the other seven provinces, including Ontario. On the financing side, the traditionally small federal share of resource revenues meant that the federal government found itself taxing residents of Ontario in the 1970's to pay equalization to other provinces because of resource wealth in Alberta. ${ }^{126}$ In what follows I consider first the sharing of resource revenues between producing provinces and the federal government, and then the interprovincial redistribution of resource revenues through the equalization system.

The federal share of resource revenues depends on the ability of the federal government to tax such revenues, an ability which has been limited by both constitutional and political considerations. Sections 92(5) and 109 of the BNA Act, $1867,{ }^{127}$ gave each province the ownership of Crown lands within its boundaries; these rights were extended to the Prairie provinces and British Columbia in the BNA Act, 1930.128 Section 125 of the BNA Act, 1867, states that "No Lands or Property belonging to Canada or any Province shall be liable to Taxation."129 The courts have interpreted this to mean that the property, including Crown corporations, of the federal government and the provinces may not be taxed by the other level of government; any government, however, may tax its own property. ${ }^{130}$

124. The $36.8 \%$ figure is equal to the UIB adjustment of one-half multiplied by one minus Quebec's share of the Canadian population $(0.264): 0.368=0.5(1-0.264)$; the term in brackets is necessary to correct for the fact that when UIB payments fall in Quebec in our example, per capita UIB in the country as a whole also falls. In per capita terms, the fall is greater in Quebec, of course, because its population is much smaller than that of Canada.

125. Courchene, supra note 117.

126. See Courchene, Equalization Payments and Energy Royalies, in NATURAL Resource RevenUes: A Test of Federalism 82 (A. Scott ed. 1976).

127. BNA Act, $1867, \S \S 92(5) \& 109$.

128. BNA Act, 1930, 20 \& 21 Geo. 5, ch. 26.

129. BNA Act, $1867, \S 125$.

130. See G. LaForest, Natural Resources and Public Property under the Canadian ConStitution 162-63 (1969), and G. LaForest, The Allocation of Taxing Power under the CanaDiAN CONSTITUTION, ch. 8 (1967). 
Thus the federal government may tax resource revenues which accrue to a private company or individual, but not those which accrue to provincial governments or their Crown corporations. This state of affairs has been criticized by Gainer and Powrie, ${ }^{131}$ and by Courchene and Melvin, ${ }^{132}$ who suggest that both equity and interprovincial balance would be improved if all resource revenues were taxed in the same manner by the federal government, independent of the recipient.

If the sharing of natural resource revenue is desirable, and if Section 125 of the BNA Act is an obstacle to sharing, then an obvious solution is to remove the obstacle with a constitutional amendment. This remedy is offered by Anthony Scott, who suggests the creation by constitutional amendment of an independent agency responsible for the distribution of resource rents. ${ }^{133}$ An alternative amendment would allow the federal government to tax provincial resource revenues and investment income in a manner consistent with its taxation of private corporate income. ${ }^{134}$ In this context, then, what is striking about the Constitution Act, 1982, is the absence of any such amendment. Like the curious incident of the dog who did not bark in the nighttime in the Sherlock Holmes story "Silver Blaze," 135 the absence of any reference to the sharing of resource revenues in the 1982 Act is clear evidence that our federal and provincial governments are not yet ready to remove the taxation anomaly created by Section 125 of the BNA Act. ${ }^{136}$

Instead of increasing federal powers with regard to resource taxation, Part VI of the Constitution Act, 1982, provides for an increase in provincial powers of taxation over natural resources. Part VI is an Amendment to Section 92 of the BNA Act, 1867, dealing with provincial powers. The Amendment did not appear in the 1980 version of the Act; ${ }^{137}$ it was added to the 1981 text in the hopes of bringing some of the western provinces onside in the arduous battle during 1981 for provincial approval of the Act. ${ }^{138}$ The Amendment authorizes the provinces to levy any taxes they wish on natural resources, and to regulate the development and management of natural resources and their export to other provinces, as long

131. See Gainer \& Powrie, Public Revenue from Canadian Crude Petroleum Production, 1 CAN. PUB. POL'Y (1975), at 1-12.

132. See Courchene \& Melvin, Energy Revenues: Consequences for the Rest of Canada, 6 CAN. PUB. POL'Y (1980), supplement at 192-204.

133. See Scott, Comment, 6 Canadian PUB. POL'y (1980), supplement at 206-10.

134. Waverman, The Visible Hand: The Pricing of Canadian Oil Resources, in 1 ENERGY POLICIES FOR THE 1980's: AN ECONOMIC ANALYsis 25-28 (1980), argues that federal (and indeed provincial) taxes on natural resources should be collected with net income taxes, rather than excise taxes, to avoid distorting production incentives, and to allow marginal oil to be produced.

135. A. Conan Doyle, The Complete Sherlock Holmes (1930), Section IV, at 23. Silver Blaze was first published in The Sirand Magazine in 1892.

136. On section 125 as an "anomaly," see Campbell, Gainer, \& Scott, Resources Rent: How Much and for Whom?' in Natural Resource Revenues: A Test Of Federalism 120 (A. Scott ed. 1976). This article is one of an excellent collection of papers on the sharing of resource revenues. The theoretical efficiency aspects of taxation and government spending in a federal country are treated in depth in several articles in a volume edited by J. Margolis, The ANalysis of Public OUTPUT (1970), and in a paper by Musgrave, Approaches to a Fiscal Theory of Political Federalism, in Public Finances: NeEds, Sources, ANd UTILIZATION (1961).

137. A draft of the Constitution Act, 1980, was announced by Prime Minister Trudeau in a Proposed Resolution for a Joint Address to the Queen respecting the Constitution of Canada. The text is reprinted in E. MCWhinney, Canada ANd the Constitution, 1979-1982, at 141-48 (1982).

138. E. MCWhinNey, supra note 137 , at 63 . 
as provincial laws do not discriminate against production exported to other provinces. These issues had arisen in two recent Supreme Court decisions involving the Government of Saskatchewan. The Court had ruled in 1977 that a Saskatchewan tax and royalty surcharge on the oil industry was ultra vires Saskatchewan because it was an indirect tax and because it attempted to regulate trade outside the province's borders. ${ }^{139}$ Then, in 1978, the Court ruled that a provincial government scheme for regulating production and prices in the potash industry was ultra vires Saskatchewan, again because it interfered with trade external to the province. ${ }^{140}$ It is probable that both cases would now be decided in favor of Saskatchewan, given Part VI of the 1982 Act. In any case, Part VI will certainly strengthen the position of the provinces as owners and managers of their natural resources.

As already pointed out, however, Part VI does nothing to facilitate the sharing of resource revenues between the producing provinces and the federal government. ${ }^{141}$ During the late 1970's the federal government's share of oil and gas revenues was only about $10 \%$, as compared to $45 \%$ each for the producing provinces and corporations. ${ }^{142}$ The small federal share of resource revenues meant that equalization and other transfers had to be financed almost entirely from nonresource taxes, which resulted in a heavy burden on Ontario relative to Alberta. Table 6 illustrates the financing of federal transfers to the provinces in 1980-81. Column 3 shows per capita payments for the three major transfer programs: equalization; Established Programs Financing (EPF) payments for health and post-secondary education; and payments for the Canada Assistance Plan (CAP), a cost-sharing program for welfare expenditures. These three programs account for about $90 \%$ of all federal transfers to provincial governments. ${ }^{143}$

Column 4 of Table 6 indicates the per capita tax payment from each province required to finance the $\$ 15.8$ billion in transfers. The tax payments are distributed among the provinces according to the distribution of total federal revenues in the Provincial Economic Accounts; ${ }^{144}$ this same procedure is used by the Economic Council. ${ }^{145}$ The net transfer in column 5 shows how the tax-transfer system redistributes revenue from Ontario and the three westernmost provinces to the rest of the country. The provinces are listed in ascending order of per capita TPI. The net transfer is inversely related to TPI except in two cases: Prince Edward Island receives a larger net payment than Newfoundland because of the former's relatively large RTS equalization payment, an anomaly discussed above; ${ }^{146}$ and Ontario makes a larger net contribution to the transfer system than British Columbia, although per capita TPI and government revenue are greater in British Columbia. Indeed, Ontario's net contribution per capita of $\$ 299$ is only $\$ 73$ less

139. Canadian Indus. Gas \& Oil Ltd. v. Government of Saskatchewan, 80 D.L.R.3d 449 (Can. 1977); see Paus-Jenssen, supra note 11 , at 45-48, 52, 53.

140. Central Canada Potash Co. v. Government of Saskatchewan, 88 D.L.R.3d 604 (Can. 1978); see

Bushnell, supra note 11, at 313-24.

141. See supre text accompanying note 12.

142. Minister of Finance, Economic Review, 1980, at 44, Table 5.7.

143. A. MacEachen, supta note 15 , at 32, Table II-2.

144. Statistics Canada, Provincial Economic ACCOUnts, 1965-80, Table 3.

145. See Economic Council of Canada, Financing Confederation 19 (1982).

146. See supra text following note 103. 
than Alberta's net contribution of $\$ 372$, despite the fact that per capita TPI is $\$ 2806$ higher in Alberta, and government revenue is $\$ 2922$ higher. ${ }^{147}$

\section{Table 6}

Net Transfer Payments with RTS Equalization, 1980-81 a (dollars per capita)

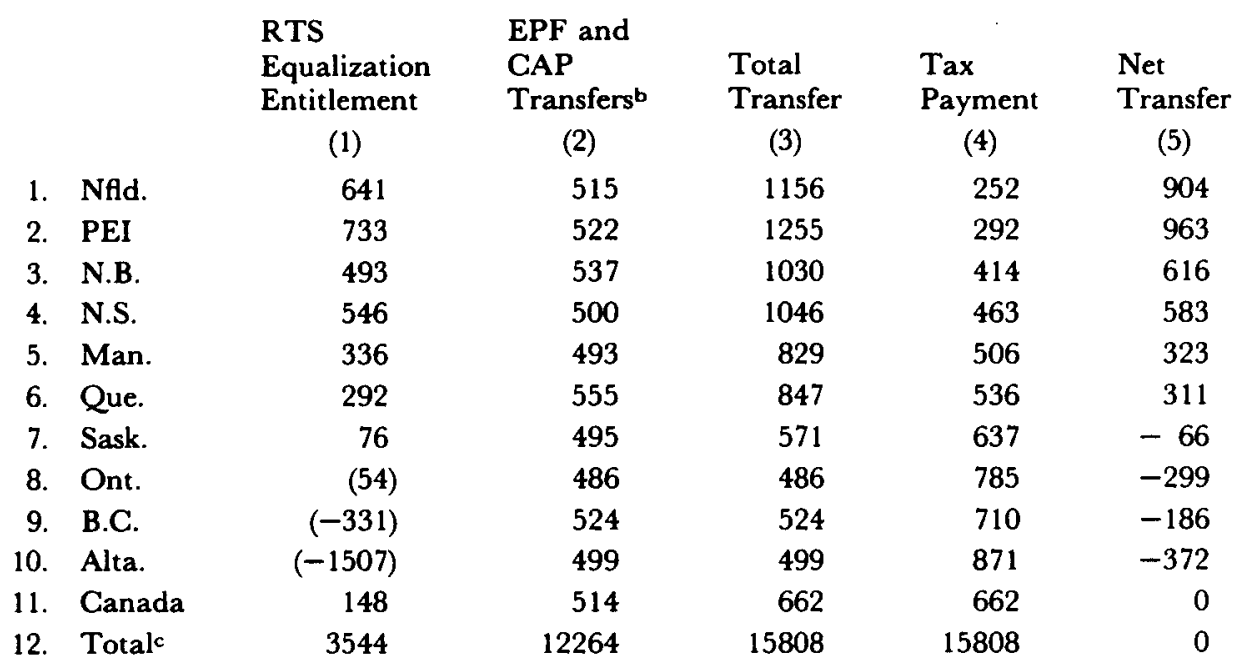

aProvinces are listed in ascending order of per capita TPI.

bTransfers for the Established Programs Financing (EPF) and Canada Assistance Plan (CAP) from the federal government to the provinces.

cTotal value in millions of dollars; line 11 is line 12 divided by the population of the ten provinces in millions.

Source by column:

1. Column 7 of Table 3; the negative figures for Alberta and British Columbia are the difference between average revenue $(\$ 1653)$ and revenue in the two provinces.

2. Department of Finance, Background Paper on Federal-Provincial fiscal Arrangements 39, 50 (1980). The Established Programs Financing (EPF) payment, including Extended Health Care payments, is $\$ 427$ per capita for each province. The Canada Assistance Plan (CAP) payment per capita is thus the difference of column 2 and 427; the CAP figure for Quebec includes the value of the province's contracting-out tax transfer of 5.0 personal income tax points.

3. The sum of columns 1 and 2 .

4. The tax payment is distributed among provinces according to the distribution of total federal revenue in Statistics Canada, Provincial Economic Accounts, 1965-1980 Catalogue 13-213, Table 3, line 35 (1982).

5. Column 3 minus column 4 .

There are two reasons why Ontario's net contribution in Table 6 is high relative to those in British Columbia and Alberta. The first is that while Ontario is lower in total income than the other two provinces, ${ }^{148}$ all three receive the same equalization payment: zero. The second is that the small federal share of resource revenues leads to the result that per capita federal revenues from all sources in Ontario are greater than in British Columbia, and fully $90 \%$ of those in Alberta.

147. See supro Table 4, col. 4 , and Table 3 , col. 3 .

148. See supra Table 4, col. 4 . 
This second problem will be alleviated by the energy agreements reached in the fall of 1981 between the three westernmost provinces and the federal government. ${ }^{149}$ Helliwell and McRae estimate that with the new agreements about $35 \%$ of oil and gas revenues over the period 1981-86 will accrue to the federal government, whose share will be nearly as great as that of the provinces. ${ }^{150}$ This will produce a substantial increase in the per capita federal revenues from Alberta over the coming years.

However, the 1981 energy agreements also exacerbate the first problem: by moving Canada toward world oil prices, the agreements will produce large revenue increases in Alberta and other producing provinces, but Alberta and Ontario will continue to receive the same zero equalization payment. The Fiscal Arrangements Act, 1982, adds local property taxes to the RTS, and equalizes to average revenue in Quebec, Ontario, Manitoba, Saskatchewan, and British Columbia. ${ }^{151}$ By excluding from the revenue standard the province of Alberta, which has $70 \%$ of the country's resource revenue, ${ }^{152}$ the RTS formula will deny a significant payment, and perhaps any payment at all, to Ontario over the next five years. Presumably, the federal government believes that it simply cannot afford an equalization payment to Ontario, given recent large federal deficits. ${ }^{153}$ Thus the problem of federal-provincial balance (i.e., the effort to reduce the federal deficit) takes priority over the problem of interprovincial balance between Ontario and Alberta.

One way to describe the Ontario problem in equalization is that while the equalization formula distinguishes among low-income provinces-the lower the province's income, the larger the payment-it does not distinguish among the high-income provinces, all of whom receive a zero payment. Distinguishing among high-income provinces suggests the possibility of "negative" equalization, in which the greater the province's income, the greater its negative payment. The problem, of course, is in collecting the negative payments from the high-income "donor" provinces. ${ }^{154}$ Four possibilities might be suggested: the federal government could raise its direct tax rates on corporations and individuals in the donor provinces, as suggested by Buchanan; ${ }^{155}$ the donor provinces might voluntarily agree to give the payments to the federal government; a constitutional amendment could allow the federal government to tax the provincial governments of donor provinces; and the

149. Memoranda of agreement on energy pricing and taxation were signed during the fall of 1981 by the Government of Canada and the Governments of Alberta (Sept. 1), British Columbia (Sept. 24) and Saskatchewan (Oct. 26); see Helliwell \& McRae, infra note 150.

150. See Helliwell \& McRae, Resolving the Energy Conffict: From the National Energy Arogram to the Energy Agreements, 8 CAN. PUB. PoL'Y, Table 2, at 20 (1982).

151. See supra note 93 and accompanying text.

152. See supra Table 3, col. 1 .

153. A. MACEACHEN, supra note 15 , at $12,13,39$, cites projected federal deficits of $\$ 7$ billion to $\$ 8$ billion in $1977-78$ to $1979-80$, in calling for restraint in federal transfers to the provinces. With the worsening recession in the early 1980 's, the federal deficit rose to about $\$ 26$ billion in 1982-83, with projections of over $\$ 30$ billion for 1983-84. See Hyman Solomon, It's Now Down to the Wire on What's in the Budget, Financial Post, Mar. 26, 1983, at 1, 2.

154. This problem is considered in Davenport, supro note 49.

155. See Buchanan, Federalism and Fiscal Equity, AMER. Econ. REv. 595, 596 (1950). 
payments could be subtracted from federal transfers other than equalization to the donor provinces.

\section{Table 7}

Net Transfers with TPI Equalization, Including UIB Adjustment and "Negative" Equalization,. 1980-81"a

(dollars per capita)

\begin{tabular}{|c|c|c|c|c|c|c|c|c|}
\hline & & & Equal & zation & Total & ransfers & & \\
\hline & & $\begin{array}{c}\text { Income Gap } \\
\text { (1) }\end{array}$ & $\begin{array}{l}\text { Basic } \\
\text { (2) }\end{array}$ & $\begin{array}{c}\text { Total } \\
\text { (3) }\end{array}$ & $\begin{array}{l}\text { Amount } \\
\text { (4) }\end{array}$ & $\begin{array}{l}\text { TPI/RTS } \\
\text { (5) }\end{array}$ & $\begin{array}{c}\text { Net Transfer } \\
\text { (6) }\end{array}$ & $\begin{array}{c}+ \text { Income } \\
(7)\end{array}$ \\
\hline 1. & Nfld. & 4050 & 675 & 685 & 1200 & 1.04 & 948 & .234 \\
\hline 2. & P.E.I. & 3181 & 530 & 585 & 1107 & .88 & 815 & .256 \\
\hline 3. & N.B. & 2976 & 496 & 557 & 1094 & 1.06 & 680 & .228 \\
\hline 4. & N.S. & 2269 & 378 & 495 & 995 & .95 & 532 & .234 \\
\hline 5. & Man. & 1108 & 185 & 368 & 861 & 1.04 & 355 & .320 \\
\hline 6. & Que. & 1029 & 172 & 284 & 839 & .99 & 303 & .294 \\
\hline 7. & Sask. & 667 & 111 & 311 & 806 & 1.41 & 169 & .253 \\
\hline 8. & Ont. & -546 & -91 & 77 & 563 & 1.16 & -222 & .407 \\
\hline 9. & B.C. & -1291 & -215 & -56 & 468 & .89 & -242 & .187 \\
\hline 10. & Alta. & -3352 & -559 & -352 & 147 & .29 & -724 & .216 \\
\hline 11. & Canada & 0 & 0 & 148 & 662 & 1.00 & 0 & - \\
\hline 12. & Totalb & 0 & 0 & 3544 & 15808 & 1.00 & 0 & - \\
\hline
\end{tabular}

aProvinces are in ascending order of per capita TPI

bTotal value in millions of dollars; line 11 is line 12 divided by the population of the ten provinces in millions.

Source by column:

1. Column 4 of Table 4: the difference between 9885 and provincial TPI.

2. Column 1 times one-sixth.

3. Column 2 plus 148 plus the UIB adjustment in column 3 of Table 5 .

4. Column 3 plus the EPF and CAP transfers in column 2 of Table 6.

5. Column 4 divided by column 3 of Table 6 .

6. Column 4 minus the tax payment in column 4 of Table 6 .

7. Column 6 divided by column 1 .

A scheme implementing this last possibility is illustrated in Table 7, using the TPI system with an adjustment for UIB, now applied to all provinces. Equation (1) on page 129 above is replaced by

$$
e_{i}=\alpha\left(Y_{c}-Y_{i}\right)+e_{c}-0.5\left(\text { UIB }_{i}-\text { UIB }_{c}\right)
$$

The first term is a fraction of the "income gap" between average TPI in Canada $\left(Y_{c}\right)$ and provincial TPI $\left(Y_{i}\right)$; a value of one-sixth was chosen for $\alpha$ to produce a distribution of payments among the eastern provinces similar to the current one. ${ }^{156}$ The first term of the equation is called "basic" equalization and is displayed in column 2 of Table 7. The other two terms are a fixed per capita payment $\left(e_{c}\right)$ and the UIB adjustment discussed in the previous section. The total per capita cost of the payments is simply $e_{c}$, because the first and third terms of the equation must sum to zero, since they are deviations from the mean. The fixed payment is set at 
$\$ 148$ per capita, to keep the cost of the program at its current level. ${ }^{157}$ In a dynamic setting $e_{c}$ could be linked to GNP per capita or any other desired escalator.

Total equalization in column 3 is now positive in Ontario and negative in British Columbia and Alberta. The payment to Ontario is financed from British Columbia and Alberta, with no reduction in total equalization payments to the other seven provinces. Total transfers in column 4 are the sum of equalization and current EPF and CAP transfers; the negative equalization to British Columbia and Alberta is subtracted from the EPF and CAP transfers otherwise payable to those provinces. The message of this subtraction should be clear: in a world of scarce federal government revenue, British Columbia and Alberta simply do not require the same degree of federal assistance as the other provinces, in order to maintain an adequate level of social services. Despite its positive equalization payment, Ontario's tax contribution is still greater than the transfers it receives, so that its net transfer remains negative. Now, however, the British Columbia net contribution is slightly greater than Ontario's, and the Alberta contribution is far greater. Alberta's net contribution of $\$ 724$ per capita represents about $22 \%$ of the $\$ 3,352$ of income gap between the province and the country as a whole, as column 7 shows. All provinces are now subject to the UIB adjustment, so that all have an interest in avoiding policies which increase unemployment.

Figure 1 illustrates the redistribution of revenues produced by equation (2) and the EPF and CAP transfers, with net transfers (on the vertical axis) a negative function of TPI (in thousands on the horizontal axis). The negatively sloped dashed lines show the redistribution affected by basic equalization alone. The lengths of the solid lines show the additional redistribution produced by the zerosum UIB adjustment, the payment of the equal per capita sum $\left(e_{c}\right)$, the EPF and CAP transfers, and the taxes necessary to finance these transfers. For example, Newfoundland (province number 1 ) has a TPI of $\$ 5,835$ on the horizontal axis, with a basic payment of $\$ 675$ and a net transfer of $\$ 948$ on the vertical axis. The negative relation between the net transfer and TPI extends to all provinces, including Ontario, British Columbia, and Alberta. The TPI system with negative equalization thus succeeds in distinguishing among the three richest provinces, something which the current equalization formula is unable to do. The significant redistribution of revenues evident in Figure 1 would certainly reduce the disparities in public services in Canada, ${ }^{158}$ which is the intent of the equalization program, but would they unduly impede the efficient operation of the economy? It is to the question of efficiency that I now turn.

158. The relation between revenue transfers and public services is complex because part of any change in transfers may lead to a compensating change in provincial tax rates, and because the same service may have different costs in different provinces; see D. Clark, Fiscal NeEdS AND REVENUE EQualization GRants 2-6, 18-26 (1969). 
Figure 1

Net Transfer Payments with TPI Equalization

(dollars per capita)

Net Transfers

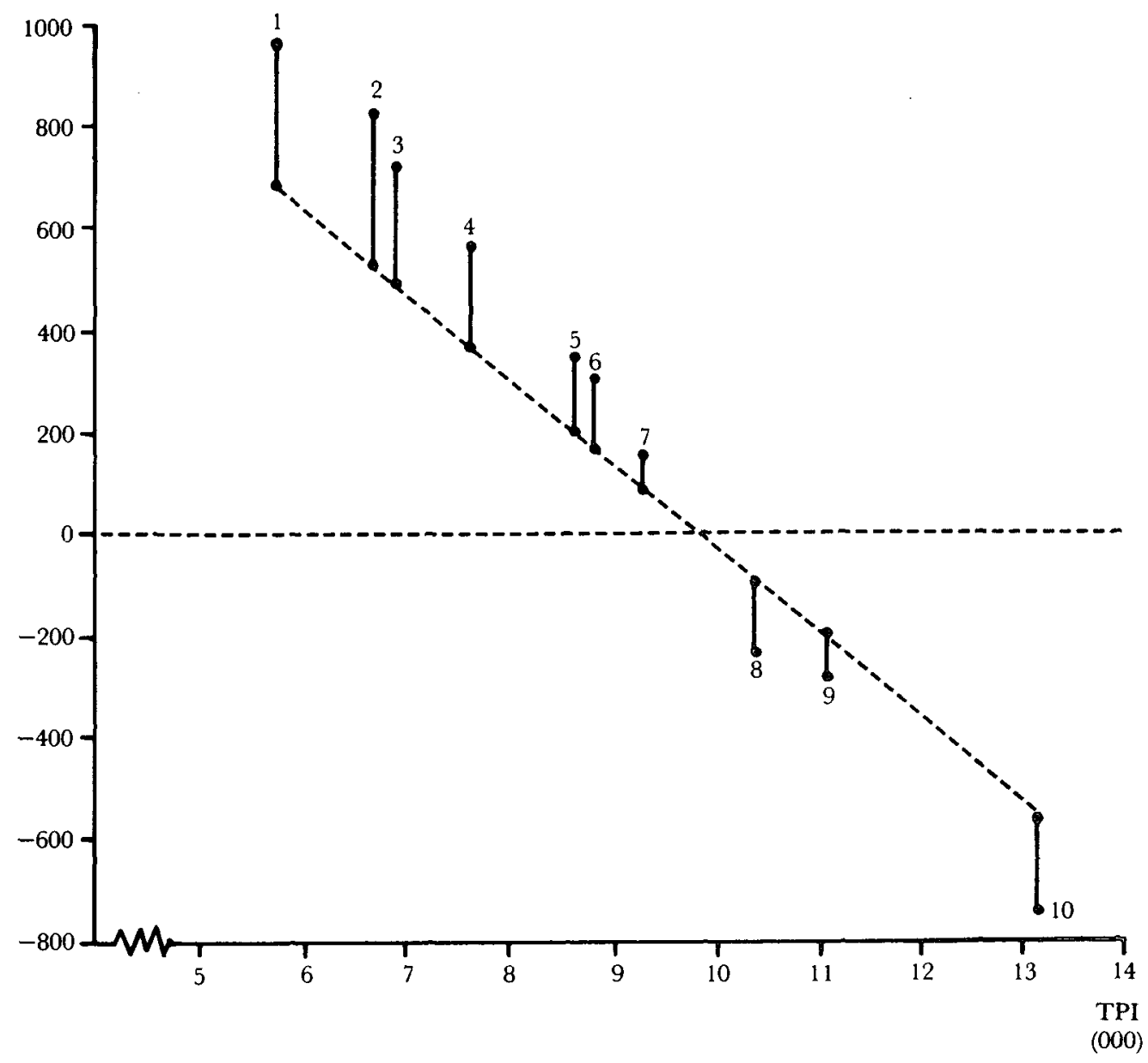

Source: Points on the negatively sloped dashed line show basic equalization from column 2 of Table 6. Numbered points at the top (provinces 1 to 7) or bottom (provinces 8 to 10) of the vertical solid lines show the total net transfers, including EPF and CAP, from column 6 of Table 6. TPI per capita is from column 4 of Table 3.

Key: Numbers refer to provinces in ascending order of TPI per capita:
1. Nfld.
2. PEI
3. N.B.
4. N.S.
5. Man.
6. Que.
7. Sask.
8. Ont.
9. B.C.
10. Alta. 


\section{VI \\ EFFICIENCY AND NATIONAL UNITY}

Central government grants to the poor provinces or states of a federal country have often been justified with reference to the principle of fiscal equity. Fiscal equity requires that similar individuals in different provinces should receive an equal net fiscal benefit, or fscal residuum, defined as the difference for an individual between government services received and taxes paid. ${ }^{159}$ Fiscal equity is thought to promote efficiency, since if the principle were violated employees might move to jurisdictions where their real productivity was lower simply to obtain greater fiscal benefits (i.e., a lower level of taxation and/or a higher level of government services), thereby reducing total output in the country. Much recent work on federal transfers to the provinces has centered on the efficiency aspects of the transfers. Thomas Courchene has stressed the inefficient impediments to labor mobility which transfers to low-income regions may create. ${ }^{160}$ Robin Boadway and Frank Flatters, ${ }^{161}$ and Lorraine Eden ${ }^{162}$ have shown that under certain conditions equalization payments may increase efficiency by reducing inefficient migration induced by resource rent differentials.

One reason for preferring the RTS to the macroeconomic approach would be the belief that the RTS satisfies the principle of fiscal equity, and therefore is more efficient than other systems. This seems to be the position of the Economic Council of Canada. ${ }^{163}$ In fact, however, the current RTS formula bears little relation to the kind of system one would design on fiscal equity principles. With regard to resource revenues, fiscal equity would demand a rigorous full equalization financed from the resource-rich provinces, so that after equalization Alberta and Ontario would have the same per capita resource revenues. The current formula equalizes less than half the revenues, and finances the payments with general taxes on all provinces. ${ }^{164}$ The Economic Council appears to favor an approach in which about $17.5 \%$ of resource revenues would be included in the RTS formula, but this is quite inconsistent with fiscal equity as it is usually defined. ${ }^{165}$

With regard to non-resource taxes on provincial residents (income, sales, etc.), it is not clear that fiscal equity requires that any equalization be paid. It is for this

159. Cf. Buchanan, supra note 155, at 588-91; Graham, Fiscal Adjustment in a Federal Country, 10-11, in Intergovernmental Fiscal. Relationships (1964); and Buchanan \& Wagner, An Efficiency Basis for Federal Fiscal Equalization, in The ANAlysis of Public OUTPUT (1970). Buchanan and Wagner analyze fiscal equity in formal models of public goods and migration in a federal country.

160. See Courchene, supra note 117 , at 159-68

161. See Boadway \& Flatters, Efficiency and Equalization Payments in a Federal System of Govermment: A Synthesis and Extension of Recent Results, 15 CAN. J. ECON. (1982).

162. See Eden, Fiscal Equity and Equalization Payments (paper presented to the Canadian Econornics Ass'n Annual Meeting, Halifax, May 27, 1981).

163. See Economic Council of Canada, supra note 145.

164. ECONOMIC Council of Canada, supra note 145, estimates that net of taxes paid to finance equalization, Manitoba, Quebec, and the Atlantic Provinces received $\$ 767$ million in equalization with respect to natural resource revenues, of which $\$ 431$ million was financed with taxes paid in Ontario. The remaining $\$ 336$ million in financing was contributed by the three westernmost provinces, which is about $5 \%$ of the $\$ 6660$ million in total resource revenues in those provinces.

165. Id. at $46-47,122$. 
reason that the term tax equity was used above to describe the goal of the RTS. Allowing governments to raise average revenue with average tax rates is in fact different from the fiscal equity goal of equal net fiscal benefits. Indeed, if provincial programs were fiscally neutral (each person receives in benefits just what he pays in taxes), then fiscal equity would require that equalization not be paid with regard to residence-based taxes, so that people in poor provinces would have inferior government services which accurately reflect their inferior market income.

Thus, if strict fiscal equity is the goal of equalization, the equalization of taxes on provincial residents requires non-neutrality of net fiscal benefits. The present system of fully equalizing such taxes is correct only in the very special case in which taxes are proportional to market income and benefits are equal in absolute amount for each taxpayer. ${ }^{166}$ The Council describes this special case, and then, astonishingly, concludes that the "present Equalization Program would, therefore, seem adequate to achieve fiscal equity with respect to residence-based taxes,"167 without any attempt to demonstrate that Canada satisfies the conditions of the special case. In fact, provincial and local taxes are not proportional to market income but regressive; benefits are progressive, but not nearly so much as being equal per capita; ${ }^{168}$ hence net benefits are much less progressive than in the special case, and the amount of equalization of taxes on residents which is consistent with fiscal equity is considerably less than in the special case. ${ }^{169}$

One can still argue, of course, that even the current RTS is closer to the principle of fiscal equity than is a macroeconomic approach; but like all second best arguments this would be difficult to sustain as a general proposition, and in any case is a much weaker position than one that claims that RTS is consistent with fiscal equity. In my view, equalization should be justified not in terms of efficiency, but as a redistributive program which reduces the disparities in public and private services among the provinces. The federal government should pursue efficiency in other ways: by working to restore a fully free common market within Canada, reducing barriers to international trade, creating an effective competition policy, and linking our energy prices to world levels, for example. Such policies will favor some regions and penalize others equalization is then the glue that holds the country together in the face of the uneven incidence of federal policies and the uneven distribution of resources. Equalization may thus contribute to efficiency to the degree that it makes federal economic policies based on efficiency considerations politically possible. Conversely, the decline or abolition of equalization might well lead to a less efficient Canadian economy by undermining the

166. See Davenport, Equalization and Fiscal Equity (manuscript 1982).

167. See Economic Council of Canada, supra note 145 , at 30.

168. See Gillespie, On the Redistribution of Income in Canada, 24 CAN. TAX J. 417-50, Tables 2, A-6, and A.7 (1976).

169. Gillespie, supra note 168 , finds that the sum of provincial and local taxes is in fact proportional not to market income, but to market income plus transfers and the benefits from government spending on goods and services (Gillespie, Table A-7). The benefits from provincial and local government spending, on the other hand, seem to be distributed about half in lump-sum form, and half in proportion to market income (Gillespie, Tables 2 and A-6). Under these conditions strict fiscal equity probably requires that less than one-half of provincial revenues from residence-based taxes be equalized. See Davenport, supra note 166 , for a preliminary analysis, which parallels that of Boadway and Flatters, supra note 161, at 628-30. 
power of the federal government, and the will of the provinces, to pursue policies consistent with a more open and competitive economy.

In this context we may consider a 1966 statement on the purpose of equalization by Mitchell Sharp, then Minister of Finance:

They [equalization payments] represent one of the dividends of Canadian unity, designed as they are to enable all Canadians to enjoy an adequate level of provincial public services. Where circumstances-whether natural or man-made-have channelled a larger than average share of the nation's wealth into certain sections of the country, there should be a redistribution of that wealth so that all provinces are able to provide to their citizens a reasonably comparable level of basic services, without resorting to unduly burdensome levels of taxation. ${ }^{170}$

This statement contains elements of both fiscal redistribution and of tax equity. If we interpret the last clause to mean "with equal tax rates," then Sharp is thinking in terms of tax equity, and the RTS formula is appropriate. But "burdensome" could also be interpreted in terms of the relative level of per capita income in a province: thus comparing $\mathrm{A}$ and $\mathrm{C}$ in Table 2, the $20 \%$ tax rate might be seen as reasonable in $A$ but unduly burdensome in $\mathrm{C}$, because it pushes after-tax income in $\mathrm{C}$ to a very low level. If this interpretation were used, we could justify an equalization payment from $\mathrm{A}$ to $\mathrm{C}$ in a manner consistent with fiscal redistribution.

Alternatively, "burdensome" might be defined in terms of a specific progressive tax formula, such as

$$
\mathrm{T}_{\mathrm{m}}=0.6(\mathrm{Y}-60)
$$

where an actual tax $T$ greater than $T_{m}$ is "unduly burdensome." Thus equalization would allow each province to collect $T_{m}$ in taxes and still acquire the average revenue. In the example in Table $2, T_{m}$ is 7.2 for $C$, and $C$ should receive an equalization payment of 2.8 , which added to $T_{m}$ and the resource revenues of 18 allow it to reach the average revenue of 28 . Thus $C$ receives a payment while $A$ does not, a result consistent with the TPI calculation in Table 2 , but in conflict with the RTS result. In any case it seems highly unlikely that when Sharp spoke of enabling "all Canadians to enjoy an adequate level of provincial public services," he envisaged a situation in which revenues would be transferred from a high-income province to a low-income province to maintain an equality in hypothetical tax rates-for the low-income province involved, this transfer would not appear as "one dividend of Canadian unity."

\section{VII}

\section{CONCLUSION}

The entrenchment of the principle of equalization in the Canadian Constitution leaves unresolved the uncertainties about the purposes of equalization, and particularly whether the program's primary goal is fiscal equity, tax equity, or fiscal redistribution. The frequent ad hoc changes to the Representative Tax System formula over the last decade imply that the RTS is not adequately fulfilling the purposes of equalization as these are interpreted by federal officials and politicians. The problems with the RTS will become even more apparent if one of

170. Proceedings of the Federal-Provincial Tax Structure Committee, Ottawa, Sept. 14 and 15, 1966, at 15. 
the Atlantic Provinces should begin to receive significant oil and gas revenues, because of the heavy weight given to such revenues in the current formula.

My own preference is for an equalization system based on fiscal redistribution, with a macroeconomic formula using total provincial income. Moreover, the integration of some form of cost-sharing for unemployment insurance benefits into the equalization program would greatly reduce the incentives for inefficient provincial economic policy induced by UIB and other federal transfers. Rising resource prices and rents will presumably increase interprovincial disparities over the next five to ten years, which in turn will induce an increased political and academic interest in the equalization program. Thus the entrenchment of equalization in the constitution heralds the beginning, rather than the end, of a vigorous debate over the proper extent and form of wealth sharing in the Canadian federation. 
